\title{
ADVANCES IN HYDROGEOCHEMICAL INDICATORS FOR THE DISCOVERY OF NEW GEOTHERMAL RESOURCES IN THE GREAT BASIN, USA
}

Geothermal Technology Advancement for Rapid Development of Resources in the U.S. DE-FOA-0005522

May 20, 2013

Principal Investigator: Stuart F. Simmons (ssimmons@mines.edu), Geology and Geological Engineering, Colorado School of Mines, 1500 Illinois St, Golden, CO 804011887; New address as of 4/1/2013: (ssimmons@egi.utah.edu), EGI, University of Utah, 423 Wakara Way Suite 300, Salt Lake City, UT 84108

Project team: Nicolas Spycher (nspycher@lbl.gov), Eric Sonnenthal (elsonnenthal@lbl.gov), Patrick Dobson (pdobson@lbl.gov), Earth Sciences Division, MS90-1116, Lawrence Berkeley National Laboratory, 1 Cyclotron Rd., MS90-1116, Berkeley, CA 94720

\section{Introduction}

This report summarizes the results of Phase I work for a go/no go decision on Phase II funding. It is structured according to Guidelines from DoE and includes a summary of the project objectives, technical accomplishments, challenges to date, the status of each go/no go criteria, progress made under each task, budgeting and spend plan, technical readiness to enter Phase II and a Phase II work plan. The Appendix contains several technical reports (lettered A through E) that provide detailed results and discussions of the Phase I findings as well as a spreadsheet of new mineralogical data for Task 1.

\section{Project Objectives}

Phase I (2012)

In the first objective, we assessed the extent to which fluid-mineral equilibria controlled deep water compositions in geothermal systems across the Great Basin. Six systems were evaluated:

$\begin{array}{ll}\text { Beowawe } & \text { Desert Peak } \\ \text { Dixie Valley } & \text { Mammoth } \\ \text { Raft River } & \text { Roosevelt }\end{array}$

These represent a geographic spread of geothermal resources, in different geological settings and with a wide range of fluid compositions. The results were used for calibration/reformulation of chemical geothermometers that reflect the reservoir temperatures in producing reservoirs.

In the second objective, we developed a reactive -transport model of the Desert Peak hydrothermal system to evaluate the processes that affect reservoir fluid geochemistry and its effect on solute geothermometry. This included testing geothermometry on "reacted" 
thermal water originating from different lithologies and from near-surface locations where the temperature is known from the simulation. The integrated multi-component geothermometer (GeoT, relying on computed mineral saturation indices) was tested against the model results and also on the systems studied in the first objective.

Phase II (2013-14)

During this phase we will continue to apply and evaluate fluid-mineral equilibria to prove the utility/applicability of geothermometers to specific sites where industry partners will permit fluid sampling from wells and surface features. Fluids will be analyzed for a broad suite of major, minor, and trace species, including those not routinely analyzed, to test the potential of new indicator ions/species. Mineralogical studies will be extended to resolve the controls on reservoir fluid-mineral equilibria. A major goal is to test new indicator species for geothermometry based on new water analyses.

We also plan to refine the reaction-transport model of Desert Peak in order to match the present reservoir temperature and fluid flow conditions, and to validate the reliability of such simulation methods in EGS geothermal resource development. The goal is to quantify the effects of processes (i.e, boiling, mixing, cooling, mineral precipitation-dissolution) that can modify water compositions as they rise from the reservoir to the surface.

\section{Phase I Technical Accomplishments}

\section{Task I: Fluid-Mineral Equilibria (Appendices A \& B).}

We determined that partial to nearly full fluid-mineral equilibrium exits between common aqueous species and the mineral assemblage quartz (chalcedony), Na-feldspar, K-feldspar, K-mica, Mg-chlorite, and calcite in all the geothermal reservoirs studied (e.g., Fig. 1; full assessment is in Appendix A). XRD analyses and thin section petrography on drill samples (mostly cuttings) from 5 of the 6 systems (i.e., all but Desert Peak) confirm that these minerals are present and widespread in rock units penetrated by production wells (Appendix B).

The plot of aqueous silica versus temperature indicates that the quartz and chalcedony geothermometers are the most reliable indicators of reservoir temperature. The log $\mathrm{Na} / \mathrm{H}$ versus $\log \mathrm{K} / \mathrm{H}$ ratios plot on the Na-feldspar-K-feldspar equilibrium line $\left(\sim 250^{\circ} \mathrm{C}\right)$; however, application of the Na-K geothermometer overestimates the well temperatures $\left(<150\right.$ to $\left.250^{\circ} \mathrm{C}\right)$, possibly because equilibration occurs at conditions that are hotter and deeper than feed points in the geothermal wells. A linear trend in $\mathrm{Na} / \mathrm{K}$ versus temperature (Fig. 1) permits formulation of a new empirical geothermometer

$$
t^{\circ} \mathrm{C}=\frac{373}{\log \left[\frac{N a}{K}\right]-0.351}-273
$$


that needs to be tested and proven. The $\mathrm{K} / \mathrm{Mg}$ ratios are scattered with respect to $\mathrm{Mg}$ chlorite-K-mica-K-feldspar-quartz equilibria, and this results in modest to low confidence in the application of the $\mathrm{K}-\mathrm{Mg}$ geothermometer.
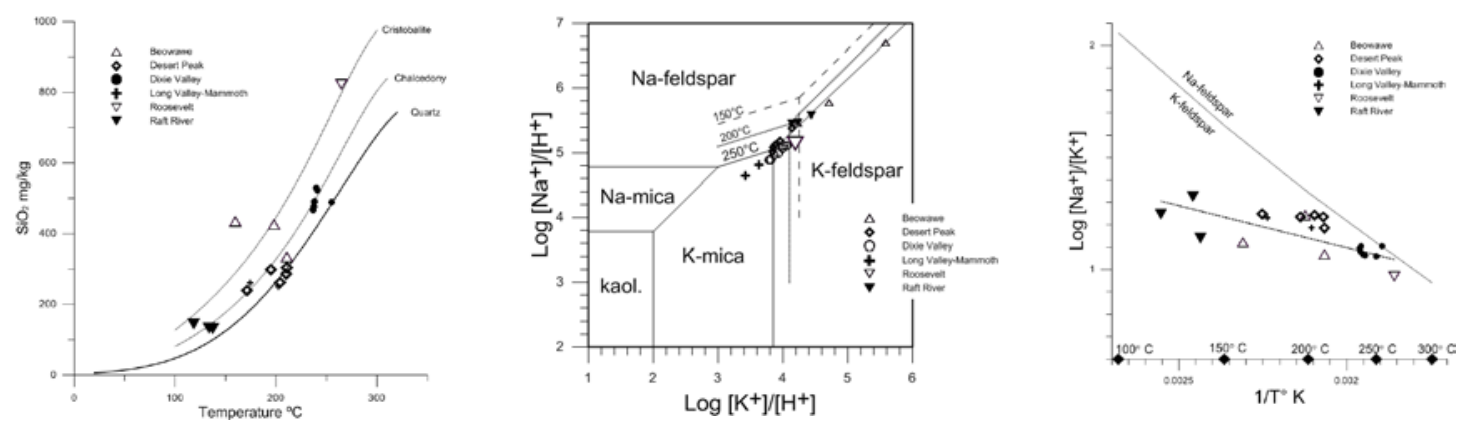

Figure 1. Examples of phase diagrams plotted with concentrations of aqueous components; the dashed linear correlation of $\log \left[\mathrm{Na}^{+}\right] /\left[\mathrm{K}^{+}\right]$vs $1 / \mathrm{T}^{\circ} \mathrm{K}$ (far right graph) is used to write a new Na/K geothermometer. See Appendix A for further description and discussion.

\section{Task II: Desert Peak Reactive-Transport Model \& GeoT Applications (Appendices C, D, E)}

The Desert Peak model (Appendix C) represents a 2-dimensional vertical slice, $2.5 \mathrm{~km}$ long and $1.4 \mathrm{~km}$ deep. The geological section was subdivided into $20 \times 20 \mathrm{~m}$ grid blocks, each of which is assigned unique hydrological, mineralogical, and thermal properties based on the stratigraphy, structure and hydrology (Fig. 2). In order to capture the fluid flow and reactive pathways through the faults and fractured rocks with differing fracture spacing, connectivity, and mineral properties, the grid was extended to consider a dualpermeability model for reactive transport.
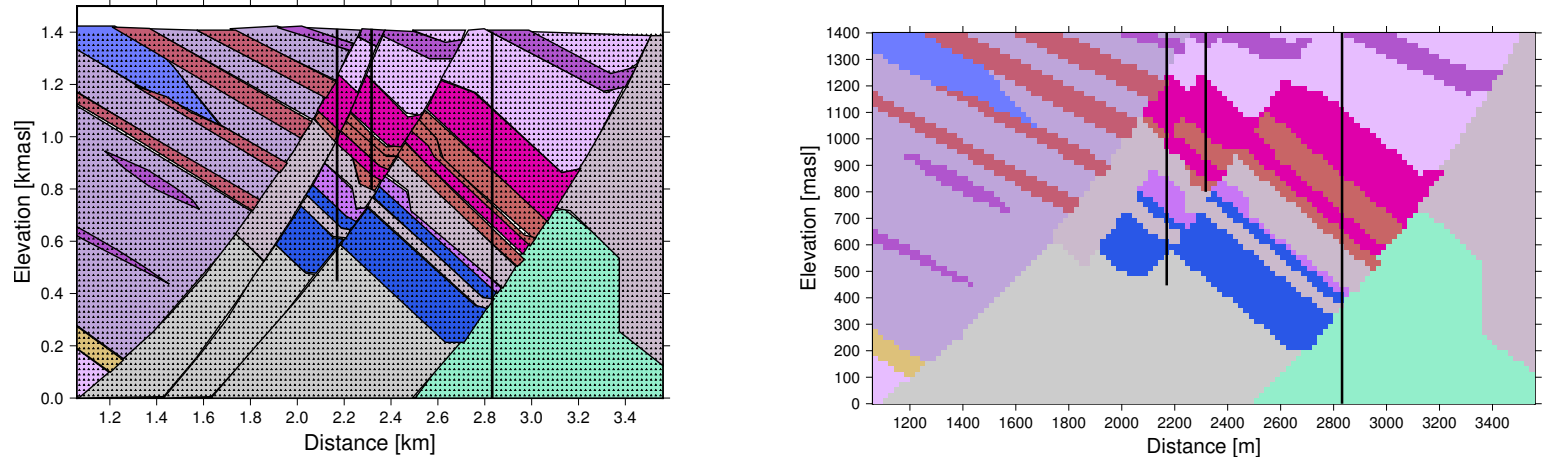

Figure 2. The Desert Peak cross section (left) showing stratigraphy and structure, and the corresponding mesh of $20 \times 20 \mathrm{~m}$ grid blocks (right).

Preliminary simulations were run to evaluate hydrological parameters and fluid-rock reactions. These simulations were limited to a 2300-year time period, and reached a reservoir temperature of only $\sim 80^{\circ} \mathrm{C}$, which is considerably less than the hottest temperature of $\sim 210^{\circ} \mathrm{C}$ measured in Desert Peak geothermal wells. Nevertheless, these early simulations provided synthetic fluid compositions that proved useful to evaluate chemical solute geothermometry methods, including multicomponent geothermometry, 
and to evaluate the trends in mineral alteration and the extent of equilibration achieved. The application of chemical geothermometers to pore water compositions closely matched the model temperatures (Fig. 3). Changes in the mineralogy due to hydrothermal dissolution-precipitation after 1000 years are shown in Figure 4.
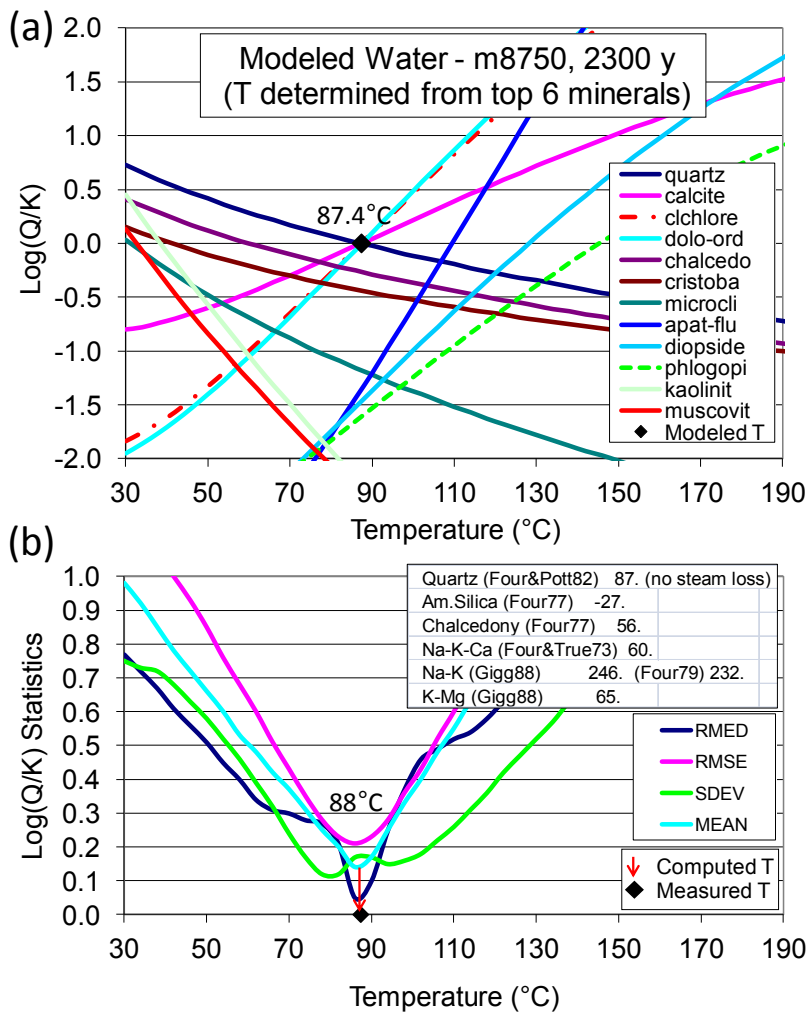

Figure 3. Determination of equilibration temperatures on synthetic deep thermal waters obtained from simulation of Desert Peak after 2300 years. (a) Computed saturation indices of key minerals. (b) Temperature estimated using program GeoT (curves show the median RMED, root-mean square error RMSE, standard deviation SDEV and average MEAN of saturation indices) and with classical geothermometers
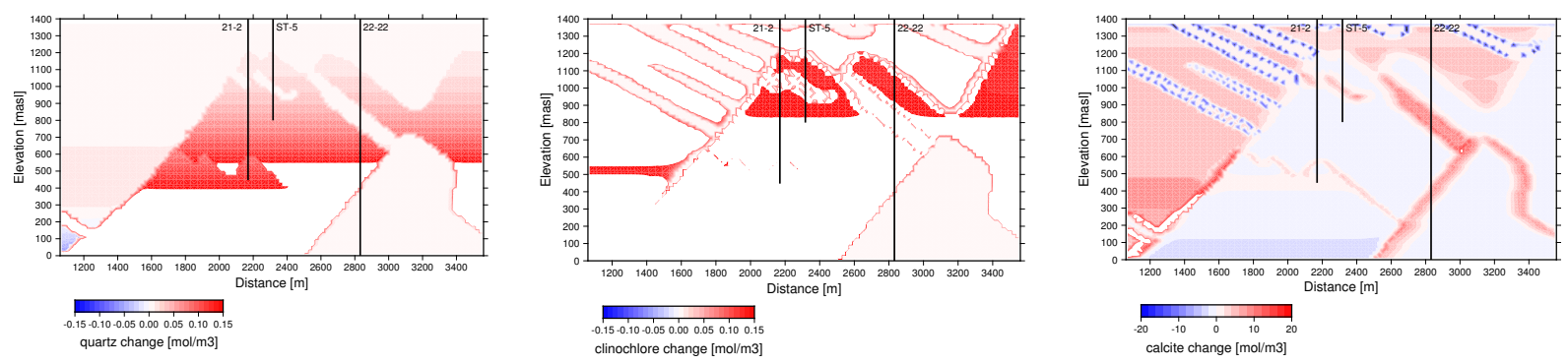

Figure 4. Change in mineral abundances (moles mineral/ $\mathrm{m}^{3}$ of rock) over 1000 years. Wells are plotted as black lines. Spotty regions of dissolution/precipitation are contouring artifacts.

GeoT, a new multi-component solute geothermometer developed by LBNL (Spycher et al., submitted), was tested by comparing the equilibration temperatures of thermal waters 
from the Great Basin to results of GeoT calculations (Appendices D \& E). GeoT uses a numerical technique to "correct" for modifications in the aqueous aluminum and magnesium concentrations in thermal waters as they rise to the surface. Consistent results were obtained, and ongoing refinements of the code will focus on methods of numerical optimization.

\section{Challenges to Date}

The most important challenges in Task 1 relate to the quality of analytical data used in the evaluations of fluid-mineral equilibria. New data for at least two of the geothermal systems (Beowawe, Roosevelt) need to be obtained because of concerns regarding the reliability of reported fluid analyses (especially in respect to aqueous $\mathrm{SiO}_{2}, \mathrm{Mg}^{+2}, \mathrm{Ca}^{+2}, \mathrm{HCO}_{3}{ }^{-}$, and $\mathrm{CO}_{2}$ ).

In Task 2, TOUGHREACT modeling of Desert Peak requires longer simulation times to bring the temperature of the system to the present state. Once the deeper rock units are added and the fault zone properties are incorporated, a 2D model that represents higher reservoir temperature and dominant fluid flow paths is achievable. This will provide the basis for evaluating the effects of shallow processes (cooling, boiling, mixing, mineral dissolutionprecipitation) on the deep reservoir fluids as they ascend to the surface.

\section{Phase I Status of Go/No Go Criteria \& Progress Under Each Task}

The milestones and metrics for both objectives/tasks are listed below, along with comments regarding the status and achievement of these.

\section{Milestones}

Task 1: Assess states of fluid-mineral equilibria in geothermal reservoirs at Beowawe, Desert Peak, Dixie Valley, Mammoth, Raft River, and Roosevelt in the Great Basin and resulting chemical geothermometers. 100\% Completed 12/31/2012.

Subtask 1.1: Compiled public domain fluid chemistry for Beowawe, Desert Peak, Dixie Valley, Mammoth, Raft River, and Roosevelt geothermal systems.

Subtask 1.2: Calculated fluid-mineral equilibria of Beowawe, Desert Peak, Dixie Valley, Mammoth, Raft River, and Roosevelt geothermal fluids. Plotted results on phase diagrams of hypothetical minerals to assess controls on sodium, potassium, magnesium, and calcium, and silica.

Subtask 1.3: Obtained XRD analyses and diffractogram interpretations for 80 rock samples from Beowawe, Coso, Dixie Valley, Mammoth, and Roosevelt. Forty-five samples have been studied and described from thin sections.

Subtask 1.4: After a careful search in thin sections of 45 rock samples, we found no fluid inclusions suitable for study.

Subtask 1.5: Calculated mineral saturation indices.

Subtask 1.6: Formulated a new empirical geothermometer based on a linear Na/K vs temperature trend. 
Other: Presented a paper at the Stanford Geothermal Workshop covering the substantive components of this task.

Task 2. Simulate a reaction-transport model for Desert Peak. 100\% Completed 3/15/2013.

Subtask 2.1: Created a two-dimensional numerical mesh and thermal-hydrological model of the Desert Peak geothermal field with the TOUGHREACT reactive transport code. Subtask 2.2: Completed a preliminary numerical simulation of the primary fluid flow pathways and temperature distributions (i.e., 2-D thermal structure).

Subtask 2.3: Incorporated primary and secondary mineral distributions into the model, using carefully reviewed thermodynamic and kinetic data, and information gained from recent experimental results.

Subtask 2.4: Simulated a preliminary model of reactive transport. The simulation was run for a period of 2300 years ( 2 days of computational time), with reservoir temperatures reaching only about $80^{\circ} \mathrm{C}$. A longer run time is required to meet the present reservoir temperature of $\sim 210^{\circ} \mathrm{C}$.

Subtask 2.5: Used GeoT to evaluate the preliminary results (synthetic fluid compositions from the reactive transport model), producing equilibration temperatures that match the end-of-run reservoir temperature $\left(\sim 80^{\circ} \mathrm{C}\right)$.

Subtask 2.6: Used GeoT to evaluate the equilibration temperatures of fluids studied in Task 1 giving consistent results.

\section{$\underline{\text { Metrics }}$}

Task 1. Determine the extents of fluid-mineral equilibria in 5 geothermal systems based on what can be observed in the rocks/minerals studied and the existing water chemistry that is in the public domain. For geothermal systems where full to partial equilibrium exists, revised/new geothermometers will be formulated for further testing and calibration.

Achieved all metrics for 6 (not 5) geothermal systems as data for Raft River became available courtesy of Joe Moore, EGI, University Utah.

Task 2. Quantitatively determine the effects of chemical and physical processes that potentially modify compositions of hydrothermal fluids as they rise from the reservoir to the surface in the Desert Peak geothermal system using the TOUGHREACT reactive transport code.

Much of the time-consuming work in the development of the reactive transport model of Desert Peak was completed, with input of thermal and hydrological data. Preliminary simulations were performed, proving the viability of the methodology. Specifically, the outcomes showed that mineral alteration patterns could be simulated and multicomponent geothermometry tested. The run time and model domain need to be extended to achieve higher temperatures comparable to present day reservoir temperatures. All other aspects of the metric were achieved. 


\section{Summary}

The main objectives of year 1 were achieved. We demonstrated that fluid-mineral equilibria exist in geothermal reservoirs across the Great Basin and that they can be used for formulating chemical geothermometers. The unexpected linear trend in the $\mathrm{Na} / \mathrm{K}$ ratio is amenable for writing a new chemical geothermometer, but further testing is required to prove its viability. We also demonstrated that numerical simulation involving coupled thermal, hydrological, and chemical modeling can provide a test bed for assessing time dependent changes in hydrothermal fluid compositions.

Future research will be directed at detailing the effects of fluid-mineral equilibria and proving chemical geothermometers for resource evaluation in geothermal systems across the Great Basin. This will involve acquisition of new geothermal fluid and mineralogical data. The numerical modeling of Desert Peak will be refined to produce an outcome that matches present reservoir temperature and alteration mineralogy. These results will then provide the framework for quantifying the details of shallow effects (e.g., boiling, mixing, cooling, mineral precipitation-dissolution) on the fluid chemistry. The results can also be used to identify regions of the system, which may be reached by shallow wells that retain fluid characteristics reflecting the hotter, underlying geothermal reservoir.

\section{Appendices (separate files)}

Appendix A: Fluid-Mineral Equilibria in Geothermal Resources of the Great Basin, Stuart F. Simmons, 14 pp.

Appendix B: Spreadsheet of Mineralogical Data from Great Basin geothermal systems, Stuart F. Simmons.

Appendix C: Thermal-Hydrological-Chemical Model for the Desert Peak Geothermal System, E.L. Sonnenthal, N.F. Spycher, P.F. Dobson, and B.M. Kennedy, 10 pp.

Appendix D: Optimized Multi-component Geothermometry applied to some geothermal area from the Great Basin, USA, L. Peiffer, N.F. Spycher, and S.F. Simmons, 16 pp.

Appendix E: Multi-component Geothermometry Summary Results using Dixie Valley Waters: L. Peiffer, C. Wanner, N. Spycher, E.L. Sonnenthal, N.F. Spycher, and B.M. Kennedy, 5 pp. 
Appendix A

\section{Fluid-Mineral Equilibria in Geothermal Reservoirs of the Great Basin}

Advances in Hydrogeochemical Indicators for the Discovery of New Geothermal Resources in the Great Basin, USA

DE-FOA-0005522

First Draft September 4, 2012

Revised March 15, 2013

Author:

Stuart F. Simmons (Principal Investigator)

Department of Geology and Geological Engineering

Colorado School of Mines

1500 Illinois St

Golden, C0 80401-1887

Tel: 303-273-3913

Email: ssimmons@mines.edu

New Address:

Energy and Geosciences Institute (EGI)

University of Utah

423 Wakara Way, Suite 300

Salt Lake City, UT 84108

Tel: 801-581-4122

Email: ssimmons@egi.utah.edu 
Appendix A: DE-FOA-0005522

\section{Table of Contents}

Summary $\quad 3$

$\begin{array}{ll}\text { Introduction } & 3\end{array}$

$\begin{array}{ll}\text { Data Sets } & 3\end{array}$

$\begin{array}{lr}\text { Computations } & 4\end{array}$

$\begin{array}{lc}\text { Results } & 4\end{array}$

$\begin{array}{lr}\text { Discussion \& Conclusions } & 6\end{array}$

$\begin{array}{lr}\text { References } & 7\end{array}$

$\begin{array}{lr}\text { Figure } 1 & 8\end{array}$

$\begin{array}{lr}\text { Figure } 2 & 9\end{array}$

$\begin{array}{lr}\text { Figure } 3 & 10\end{array}$

Figures $4 \& 5+11$

Figures $6 \& 7 \quad 12$

$\begin{array}{ll}\text { Table } 1 & 13\end{array}$

Tables $2 \& 3$ 


\section{Summary}

Partial to nearly full fluid-mineral equilibria exists between common aqueous species in reservoir fluids and the mineral assemblage quartz (chalcedony), Na-feldspar, K-feldspar, K-mica, Mg-chlorite (clinochlore), calcite, and heulandite in Great Basin geothermal systems. For chemical geothermometry, the silica geothermometer based on quartz/chalcedony solubility appears to be the most reliable indicator of reservoir temperature. Although $\mathrm{Na} / \mathrm{H}$ vs K/H ratios plot on the $\mathrm{Na}-$ feldspar-K-feldspar equilibrium line $\left(\sim 250^{\circ} \mathrm{C}\right)$, application of the $\mathrm{Na}-\mathrm{K}$ geothermometer overestimates reservoir temperature, possibly because equilibration occurs at conditions that are hotter and deeper than existing feed points in geothermal wells. A linear trend in $\mathrm{Na} / \mathrm{K}$ versus temperature permits formulation of a new empirical geothermometer

$$
t^{\circ} \mathrm{C}=\frac{315}{\log \left[\frac{N a}{K}\right]-0.467}-273
$$

that has yet to be tested and proven. Modest to low confidence in the application of the $\mathrm{K}-\mathrm{Mg}$ geothermometer is expected because the reservoir $\mathrm{K} / \mathrm{Mg}$ ratios are scattered with respect to $\mathrm{Mg}$ chlorite-K-mica-K-feldspar-quartz equilibria. Future work will require acquisition of new geothermal water samples and analyses to confirm trends and advance development of hydrogeochemical indicators.

\section{Introduction}

This report describes results of an assessment of fluid-mineral equilibria for six geothermal systems in the Great Basin: Beowawe, Desert Peak, Dixie Valley, Mammoth, Raft River, and Roosevelt. Using water chemistry mostly in the public domain (Desert Peak data supplied by Mack Kennedy; Raft River data supplied by Bridget Ayling and Joe Moore), speciation calculations were computed using WATCH and SOLVEQ, and ion activities (i.e., thermodynamic concentrations) of indicator species $\left.\mathrm{CH}^{+}, \mathrm{Na}^{+}, \mathrm{K}^{+}, \mathrm{Ca}^{++}, \mathrm{Mg}^{++}, \mathrm{HCO}_{3}-\mathrm{SiO}_{2}\right)$ were plotted on phase diagrams computed using Geochemist Workbench (Bethke, 1996). This approach was first summarized by Garrels and Christ (1965). The selection of species and minerals for assessment follows Giggenbach (1988, 1991) and Fournier $(1981,1985,1991)$ who developed a set of chemical geothermometers that have broad application in geothermal resource assessment.

\section{Data Sets}

Analyses of reservoir water compositions (Table 1) represent a spectrum of geothermal reservoirs of low to high temperature across the Great Basin. All the waters are near neutral pH. Chloride (350 to $>5000 \mathrm{mg} / \mathrm{kg} \mathrm{Cl}$ ) is the dominant anion at Desert Peak, Dixie Valley, Roosevelt, and Raft River, whereas bicarbonate $\left(145->400 \mathrm{mg} / \mathrm{kg} \mathrm{HCO}_{3}\right)$ is the dominant anion at Beowawe and Long ValleyMammoth. Sulfate is a minor anion, with concentrations (30 to $>200 \mathrm{mg} / \mathrm{kg} \mathrm{SO4}$ ) that are sub-equal with bicarbonate.

Gas data (Table 2) are only available for Dixie Valley and Desert Peak. For these two systems, the gas data were combined with water chemistry data to determine reservoir water compositions on which speciation calculations were computed.

Temperature data (Table 1) represent maximum measurements from well surveys or interpretations from enthalpy data. All reservoirs are assumed to comprise single phase liquid-only. 
Mineralogical analyses (XRD, thin section) of Beowawe, Dixie Valley, Mammoth, and Roosevelt confirm that quartz, feldspars (Na-feldspar, K-feldspar, plagioclase), illite (K-mica), chlorite, and calcite are common minerals in the reservoir rocks and that these are most likely to have the greatest influence on fluid-mineral equilibrium.

\section{Computations}

Having compiled and formulated available water and gas analyses into a coherent data set, speciation calculations were undertaken using the computer code WATCH 2.0. This code is available for free from ISOR (Iceland Geosurvey; http://geothermal.is/software/software), and the most recent version is modified and updated from the one that was initially written by Stefán Arnórsson, Sven Sigurđsson and and Hörđur Svararson (e.g., Arnórsson et al., 1982, 1983a, 1983b).

WATCH input requires water and gas (if available) analyses, $\mathrm{pH}$, temperature/pressure of sampling, and well enthalpy or reservoir temperature. The concentrations, activity coefficients, and activities of aqueous species at reservoir conditions are determined by an iterative process that involves simultaneous solution of mass balance and mass action equations, input from a standard set of thermodynamic data, and a model of ion-ion interactions based on the extended Debye-Hückel equation. The output gives concentrations of analytes at reservoir conditions, activity coefficients of aqueous species (69 total), partial pressures of dissolved gas species, and reservoir $\mathrm{pH}$, which are used to compute activities and activity ratios. These computed values are plotted on phase diagrams showing the compositional and thermal stability fields of alumino-silicate minerals and silica polymorphs (quartz, chalcedony, cristobalite). SOLVEQ is a computer code that is similar to WATCH, but setting up the inputs are time consuming. A comparative analysis of outputs from SOLVEQ and WATCH using data from Desert Peak and Dixie Valley showed that computed activities of major cations are very close (Table 3 ).

Phase diagrams were computed using Geochemists Workbench based on thermodynamic data from SUPCRT (Johnson et al., 1992). For these phase diagrams, certain zeolites, clays, feldspars and calcium alumino-silicates (i.e., beidellite, saponite, clinoptilolite, margarite, grossular, high albite, maximum microcline) were suppressed during construction in order to match the minerals occurring in the reservoir rocks.

\section{Results}

A series of phase diagrams are used to assess the state of fluid-mineral equilibria. The roles of silica phases and calcite are evaluated first, followed by assessment of sodium, potassium, calcium, and magnesium silicates. $\mathrm{Na} / \mathrm{K}$ and $\mathrm{K} / \mathrm{Mg}$ ratios are plotted as a function of well temperature to determine applicability of conventional geothermometers based on equilibrium with hydrothermal feldspars, clays, and quartz/chalcedony.

Silica

Since silicic acid $\left(\mathrm{H}_{4} \mathrm{SiO}_{4}\right)$ is a neutral species in solution, the computed value of activity for $\mathrm{SiO}_{2 \text { (aq) }}$ is within a few percent of the analyzed concentration of $\mathrm{SiO}_{2(\mathrm{aq})}$, and analytical data, corrected for steam loss, can be plotted directly on phase diagrams to evaluate equilibrium with respect to quartz, chalcedony, and cristobalite (Fig. 1). Most of the waters plot on or between chalcedony and quartz solubility curves, suggesting that these two phases are the main control on silica concentrations in geothermal reservoirs. Beowawe data are scattered with two analyses plotting 
near or above the cristobalite solubility curve; the only analysis from Roosevelt also plots near the cristobalite solubility curve.

\section{Calcite}

As shown by Ellis (1959), calcite solubility at hydrothermal conditions is a function of temperature and aqueous $\mathrm{CO}_{2}$ concentration (Fig. 2). The activity products $\left(\left[\mathrm{Ca}^{++}\right]\left[\mathrm{HCO}_{3}^{-}\right]^{2}\right)$ for waters from all the geothermal reservoirs plot close to calcite saturation curves based on the concentrations of reservoir aqueous $\mathrm{CO}_{2}$. All of the WATCH/SOLVEQ calculations indicate the waters are supersaturated in calcite. There is nil likelihood of forming a geothermometer based on calcite solubility.

\section{Sodium, Potassium, Calcium \& Magnesium Alumino-silicates}

Four similar phase diagrams (Fig. 3) portray the stability fields of alumino-silicate minerals as a function of silica concentration $\left(\log \left[\mathrm{SiO}_{2}\right]\right)$ and cation-hydrogen ion activities. The positions of the water compositions plot within or near the stability fields of K-feldspar, K-mica, albite, heulandite, and Mg-chlorite, and within the range of quartz-chalcedony solubility for respective reservoir temperatures.

\section{$\mathrm{Na} / \mathrm{K}$ and $\mathrm{K} / \mathrm{H}$ Ratios}

Figure 4 shows the positions of geothermal waters with respect to the stability fields of Na-feldspar (albite), K-feldspar, K-mica, Na-mica (paragonite), and kaolinite. The waters form a linear trend that suggests their $\mathrm{Na} / \mathrm{K}$ ratios are controlled by fluid-mineral equilibria involving Na-feldspar and $\mathrm{K}$ feldspar at $250^{\circ} \mathrm{C}$. This is true even for Mammoth where the $\left[\mathrm{H}^{+}\right]$ion activity is elevated so that waters plot in the K-mica field; a similar trend has been noted in high temperature geothermal reservoirs from New Zealand (e.g., Simmons and Browne, 2000).

Figure 5 shows the positions of geothermal waters with respect to the stability fields of K-feldspar, $\mathrm{K}$-mica, and kaolinite. The data hover about the K-feldspar-K-mica boundary, suggesting these two minerals buffer reservoir fluid $\mathrm{pH}$.

\section{K/Na and $\mathrm{Mg} / \mathrm{K}$ Ratios}

Figure 6 shows the positions of geothermal waters with respect to the stability fields of Na-feldspar and K-feldspar as a function of temperature, which is the basis for the Na-K geothermometer (Giggenbach, 1988). The data form a low angle linear trend that plot well within the K-feldspar stability field, intersecting the Na-feldspar-K-feldspar boundary around $250^{\circ} \mathrm{C}$ close to where the Dixie Valley data plot. This $\mathrm{Na} / \mathrm{K}$ trend seems to contradict the results of Figure 4, and it is possible that production well feed temperatures and depths may be cooler and shallower than the environment in which equilibrium is established; i.e., the $\mathrm{Na} / \mathrm{K}$ ratios may indicate the presence of hotter conditions at greater depth. Alternatively, geothermal waters are out of equilibrium with Nafeldspar and K-feldspar. Regardless of the correct explanation, a linear regression of the $\mathrm{Na} / \mathrm{K}$ vs temperature trend yield an empirical relationship that can be tentatively used as a substitute geothermometer:

$$
t^{\circ} \mathrm{C}=\frac{315}{\log \left[\frac{N a}{K}\right]-0.467}-273
$$


However, for a small range of $\mathrm{Na} / \mathrm{K}$ values (e.g., due to analytical error or natural variation) there is a large of range of corresponding temperatures that could easily exceed several tens of degrees $\left({ }^{\circ} \mathrm{C}\right)$, hence the usefulness of this empirical relationship needs to be proven.

Figure 7 shows the positions of geothermal waters with respect to an equilibrium condition controlled by K-mica, K-feldspar, clinochlore (14 and $7 \AA ̊$ ), and quartz. Equilibrium among these minerals and $\mathrm{K}^{+}$and $\mathrm{Mg}^{++}$is the basis for the $\mathrm{K}-\mathrm{Mg}$ aqueous geothermometer proposed by Giggenbach (1988). If the Long Valley-Mammoth and Beowawe data are ignored, Log $\left[\mathrm{Mg}^{++}\right] /\left[\mathrm{K}^{+}\right]^{2}$ values form a coherent trend that broadly follows the K-mica, K-feldspar, clinochlore (14 and $7 \AA$ ), and quartz equilibria.

\section{Discussion \& Conclusions}

These preliminary results show that despite variability in the rock types and stratigraphic columns of geothermal reservoirs across the Great Basin, quartz (chalcedony), Na-feldspar, K-feldspar, and K-mica influence the compositions of thermal waters via fluid-mineral equilibria. Accordingly, the quartz-silica and Na-K geothermometers should yield reliable temperatures, even if they reflect different temperatures and depths of equilibration.

The preceding analysis assumes the water data and temperature profiles contain minimum analytical errors. Some of the data are several decades old, and the details of measurements are missing or poorly documented. For example, some of the aqueous silica data from Roosevelt and Beowawe are too high with respect to quartz solubility. Other sources of potential error might lie in $\mathrm{pH}$ measurements, and/or analyses of $\mathrm{Mg}$ and $\mathrm{CO}_{2}-\mathrm{HCO}_{3}$ concentrations. New samples and analyses are required to confirm the trends identified in this report.

Some of the future avenues for research include investigation of: 1) the origin(s) of the linear Na/K vs temperature relationship; 2) the control of depth and temperature on equilibration points for the various mineral-aqueous ion reactions; 3 ) the role that shallow saline ground waters play in modifying geothermal water compositions during fluid movement to the surface. 


\section{References}

Arnórsson, S., Gunnlaugsson, E. and Svavarsson, H., 1983a, The chemistry of waters in Iceland.II. Mineral equilibria and independent variables controlling water compostions: Geochimica Cosmochimica Acta, v. 47, p. 547-566.

Arnórsson, S., Gunnlaugsson, E. and Svavarsson, H., 1983b, The chemistry of waters in Iceland.III. Chemical geothermometry in geothermal investigations: Geochimica Cosmochimica Acta, v. 47, p. 567-577.

Arnórsson, S., Sigurŏsson, S. and Svavarsson, H., 1982, The chemistry of waters in Iceland.I. Calculation of aqueous speciation from 0 to $370^{\circ} \mathrm{C}$ : Geochimica Cosmochimica Acta, v. 46, p. 1513-1532.

Ayling, B. and Moore, J., in press), Fluid geochemistry at the Raft River geothermal field, Idaho, USA: New data and hydrogeological implications: Geothermics.

Bethke, C. M., 1996, Geochemical Reaction Modeling Concepts and Applications: Oxford University Press, $416 \mathrm{pp}$.

Capuano, R. M., Cole, D. R., 1982, Fluid-mineral equilibria in a hydrothermal system: Geochimica Cosmochimica Acta, v. 46, p. 1353-1364.

Cole, D.R., and Ravinsky, L.I. , 1984, Hydrothermal Alteration Zoning in the Beowawe Geothermal System, Eureka and Lander Counties, Nevada: Economic Geology, v. 79, p. 759-767.

Ellis, A.J., 1959, The solubility of calcite in carbon dioxide solutions: American Journal of Science, v. 257, p. 354-365.

Fournier, R. O., 1981, Application of water geochemistry to geothermal exploration and reservoir engineering: chapter 4 in Geothermal Systems: Principles and Case Histories (L. Rybach and L. P. J. Muffler, eds.), Wiley New York, p. 109-143.

Fournier, R. O., 1985, The behavior of silica in hydrothermal solutions: Reviews in Economic Geology, v. 2: 45-62.

Fournier, R. 0., 1991, Water geothermometers applied to geothermal energy: in Applications of Geochemistry in Geothermal Reservoir Development, UNITAR-UNDP (ed. F. D'Amore), p. 3769.

Garrels, R. M., and Christ, C. L., 1965, Solutions, Minerals, and Equilibria: Harper \& Row (New York), $450 \mathrm{pp}$.

Giggenbach, W. F., 1988, Geothermal solute equilibria. Derivation of Na-K-Mg-Ca geoinidicators: Geochimica Cosmochimica Acta, vol. 52, p. 2749-2765.

Giggenbach, W. F., 1991, Chemical techniques in geothermal exploration: in Applications of Geochemistry in Geothermal Reservoir Development, UNITAR-UNDP (ed. F. D'Amore), p. 119144.

Goff, F., Bergfeld, D., Janik, C.J., Counce, D., and Murell, M., 2002, Geochemical data on waters, gases, scales, and rocks from Dixie Valley region, Nevada: Los Alamos National Laboratory Report LA-13972-MS, Los Alamos, NM.

Johnson, J.W., Oelkers, E.H., and Helgeson, H.C., 1992, SUPCRT92: a software package for calculating standard molal thermodynamic properties of minerals, gases, aqueous species, and reactions from 1 to 5000 bar and 0 to $1000^{\circ} \mathrm{C}$ : Computers in Geosciences, v. 18, p. 899-947.

Reed, M., 1989, Thermodynamic calculations of calcium carbonate scaling in geothermal wells, Dixie Valley geothermal field, USA: Geothermics, v. 18, p. 269-277.

Simmons, S. F. and Browne, P. R. L., 2000, Hydrothermal minerals and precious metals in the Broadlands-Ohaaki geothermal system: Implications for understanding low-sulfidation epithermal environments; Economic Geology, v. 95, p. 971-999.

Tempel, R. N., Sturmer, D. M., ad Schilling, J., 2011, Geochemical modeling of the near-surface hydrothermal system beneath the southern moat of Long Valley caldera, California: Geothermics, v. 40, p. 91-101. 
Appendix A: DE-FOA-0005522

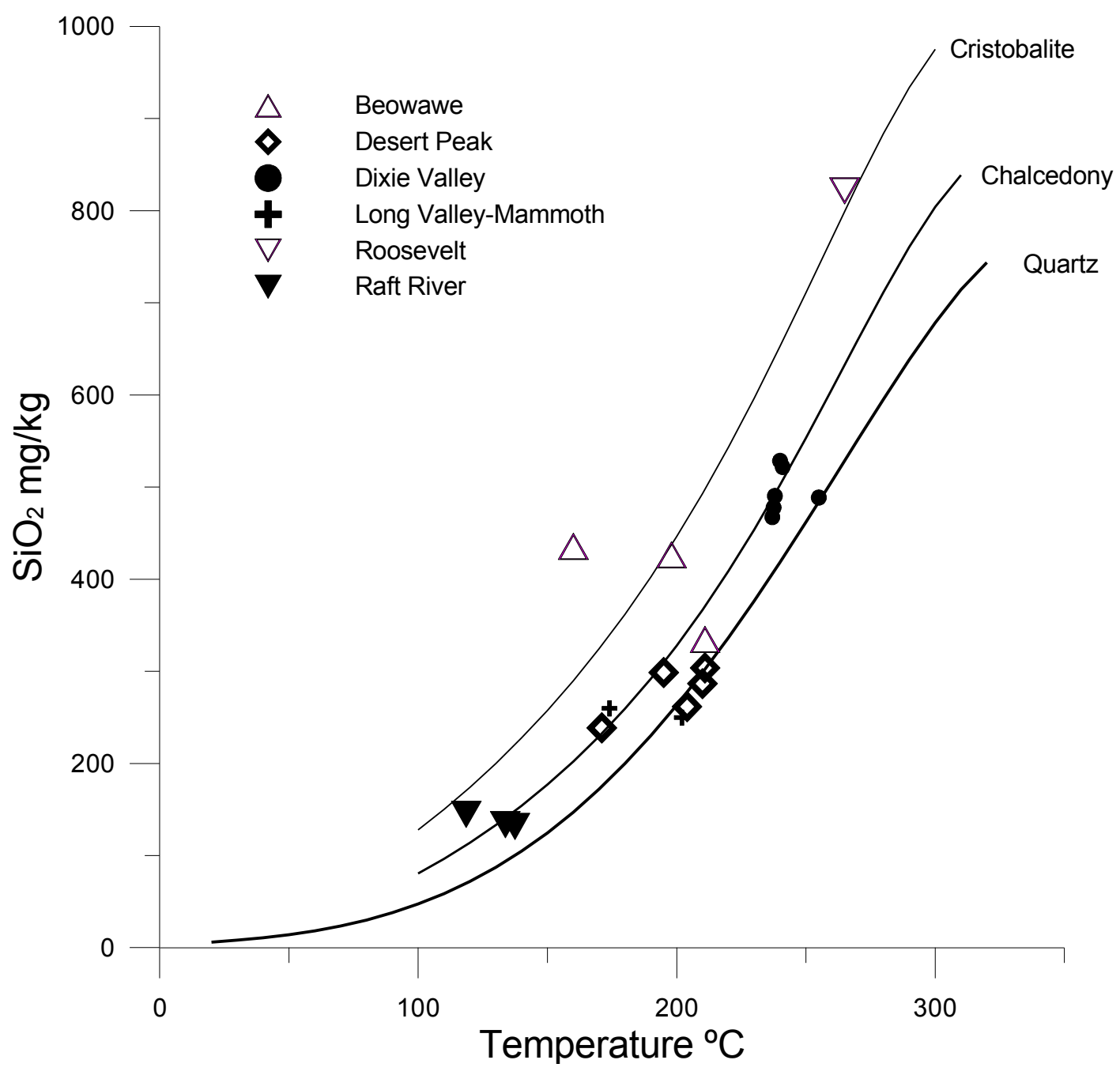

Figure 1. Analytical data for silica (Table 1) plotted as a function of temperature and solubilities of quartz, chalcedony, and cristobalite. 


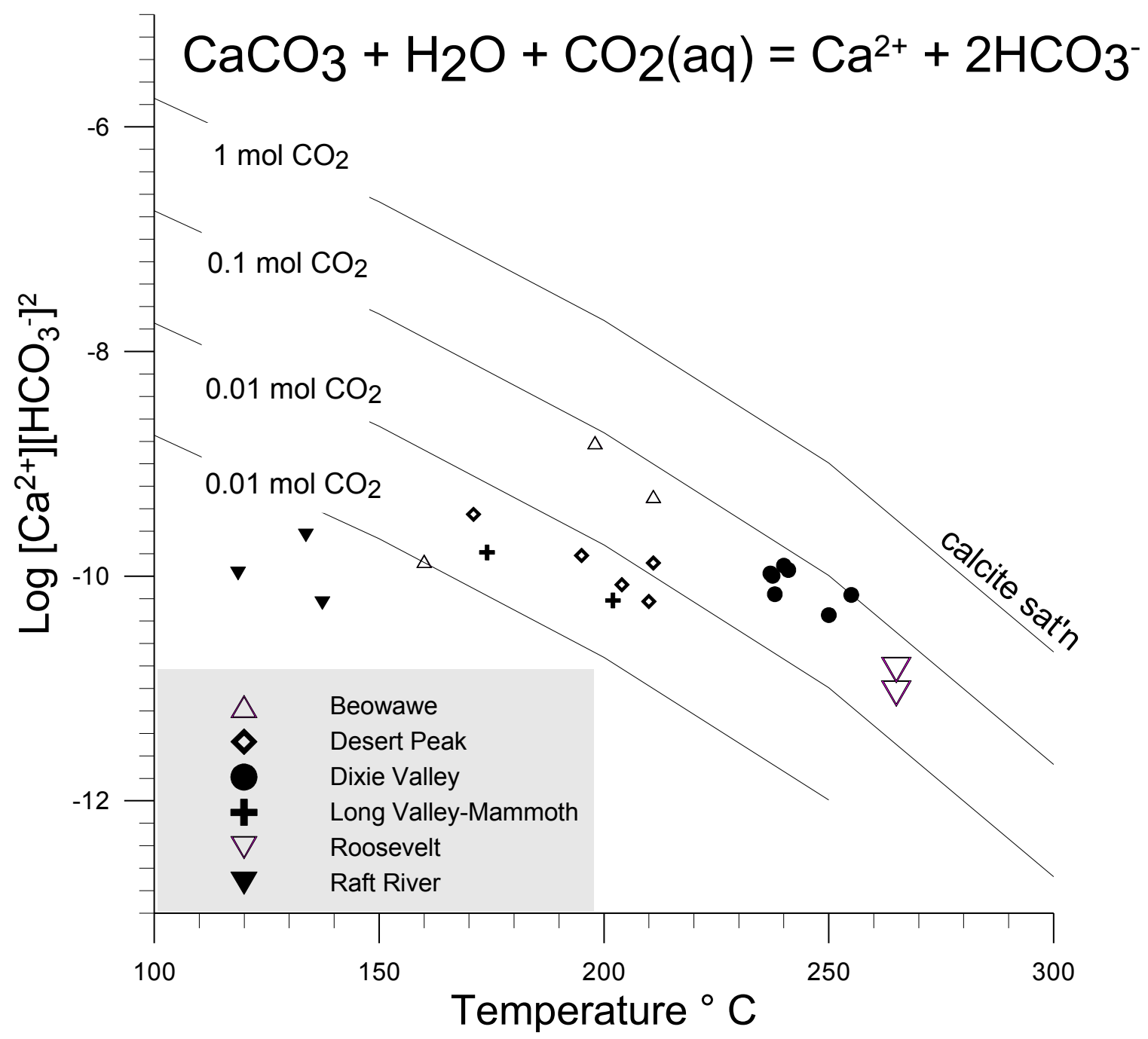

Figure 2. Activity product of $\left[\mathrm{Ca}^{++}\right]\left[\mathrm{HCO}_{3}{ }^{-}\right]^{2}$ plotted as a function of temperature. Calcite solubility curves are computed for $0.001,0.01,0.1$, and 1.0 mole/kg aqueous $\mathrm{CO}_{2}$. 

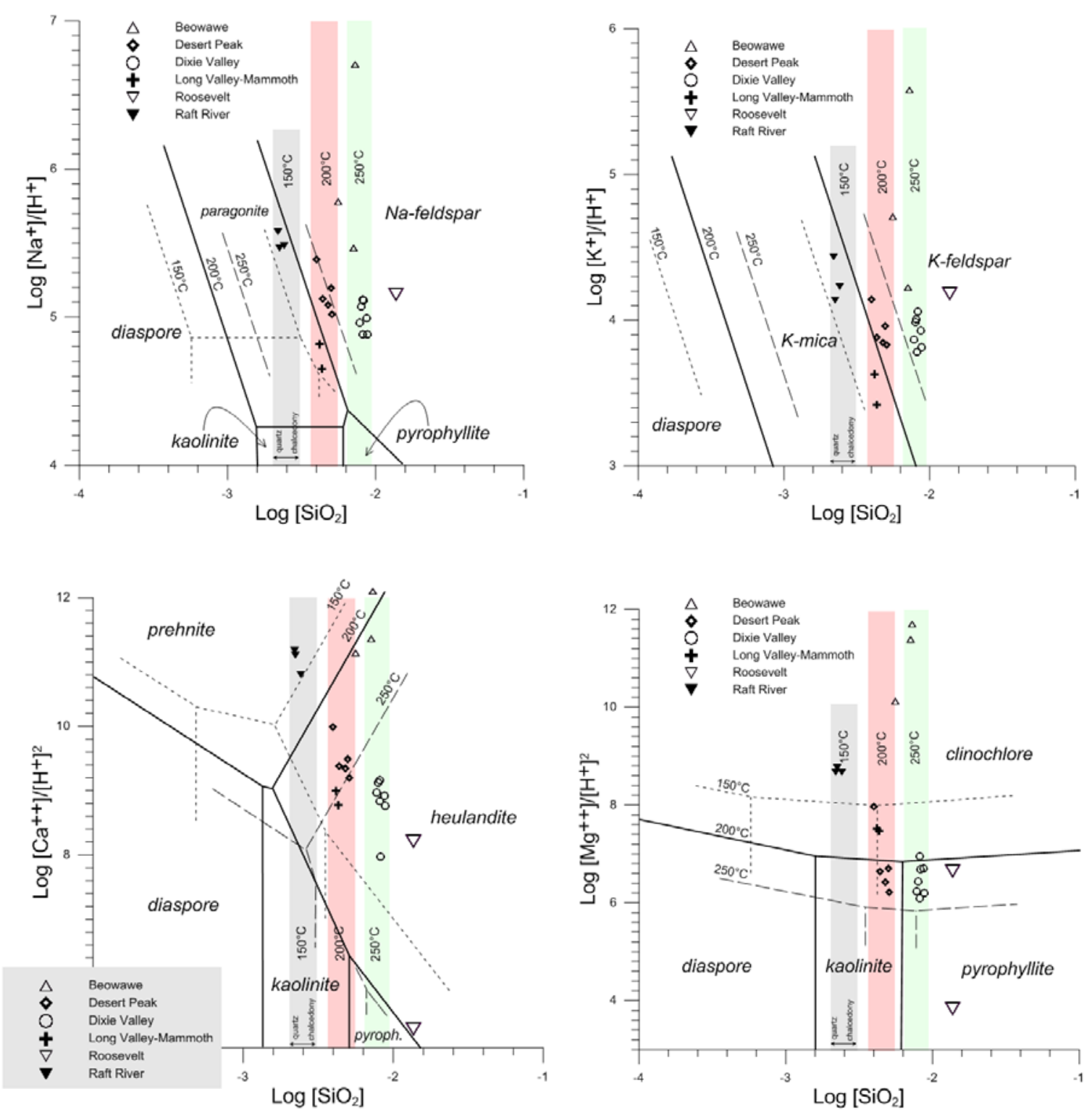

Figure 3. Activity diagrams showing the stability fields of sodium, potassium, calcium, and magnesium alumino-silicates as a function of temperature and $\log \left[\mathrm{SiO}_{2}\right]$. For each vertical field shaded grey, pink, and green, the left vertical boundary represents quartz saturation and the right vertical boundary represents chalcedony saturation. 
Appendix A: DE-FOA-0005522

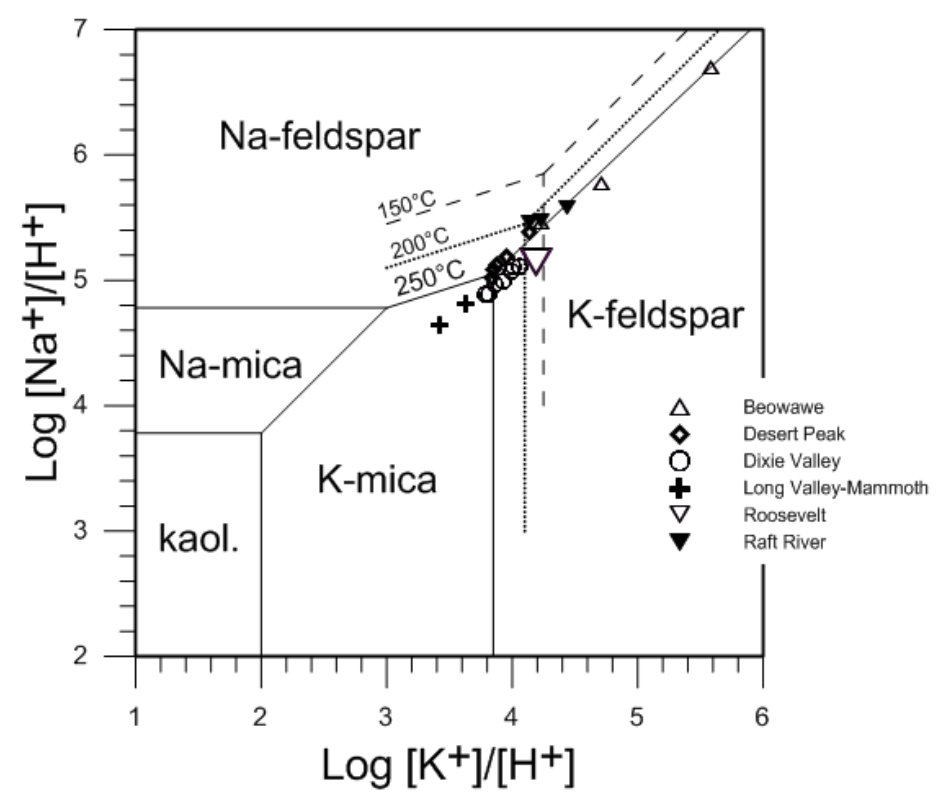

Figure 4. Activity diagram showing the stability fields of sodium and potassium aluminosilicates in equilibrium with quartz as a function of $\log \left[\mathrm{Na}^{+}\right] /\left[\mathrm{H}^{+}\right], \log \left[\mathrm{K}^{+}\right] /\left[\mathrm{H}^{+}\right]$, and temperature.

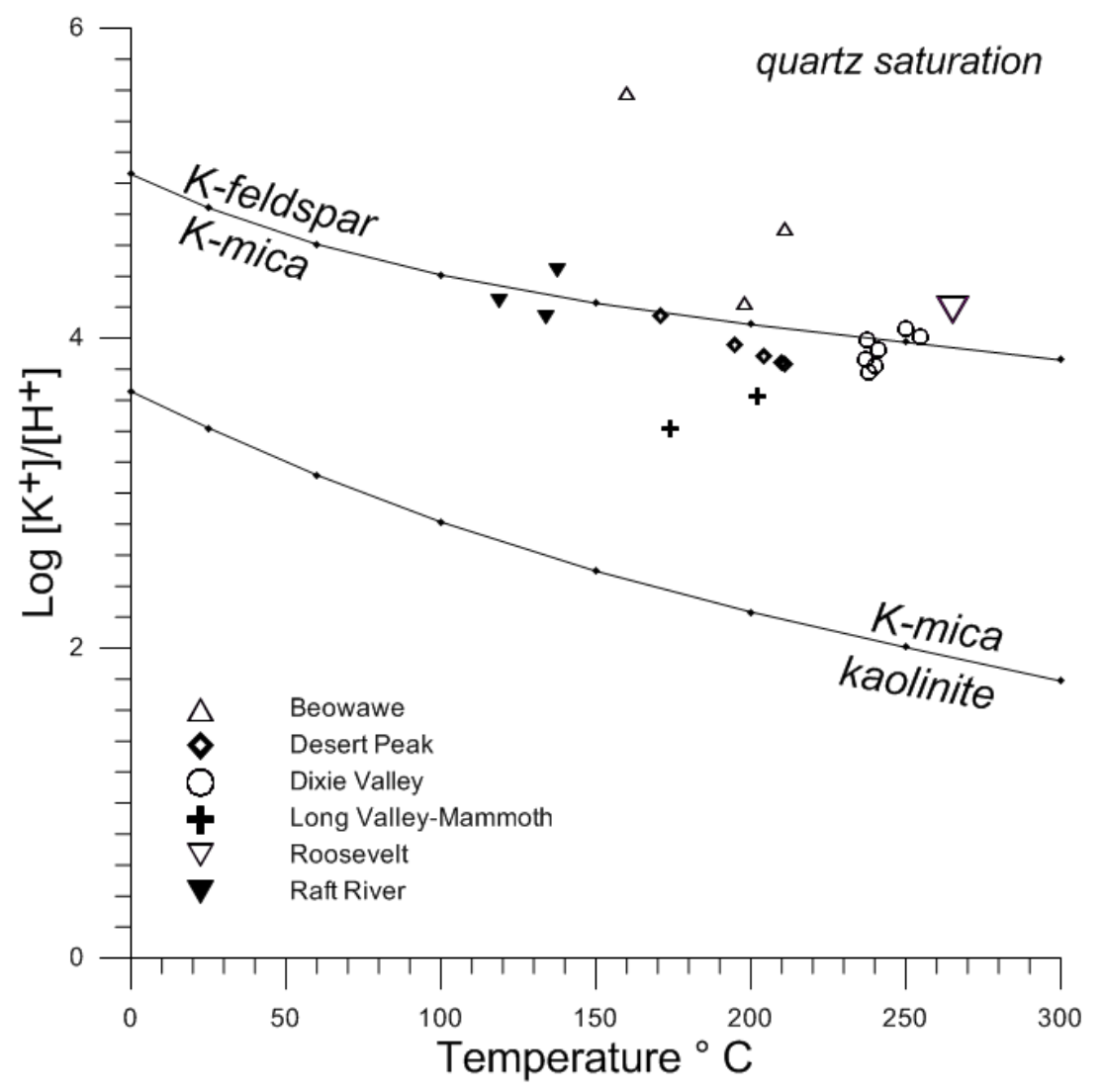

Figure 5. Aqueous compositions of $\log \left[\mathrm{K}^{+}\right] /\left[\mathrm{H}^{+}\right]$versus temperature. 


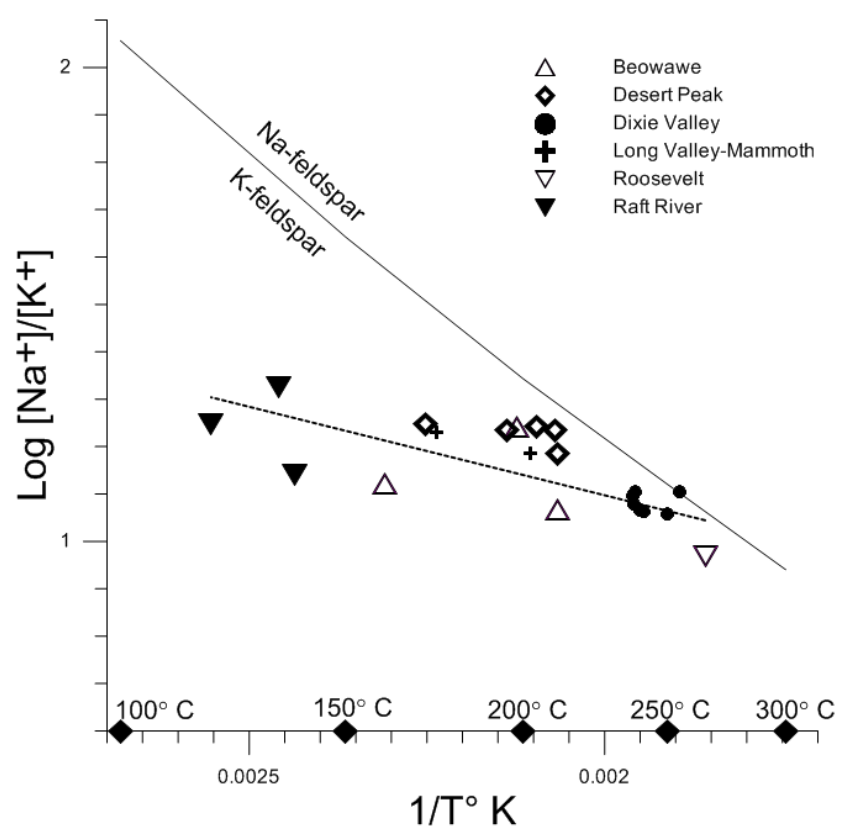

Figure 6. Aqueous compositions of $\log \left[\mathrm{Na}^{+}\right] /\left[\mathrm{K}^{+}\right]$versus temperature (after Giggenbach,1988). The dashed linear correlation of $\log \left[\mathrm{Na}^{+}\right] /\left[\mathrm{K}^{+}\right]$vs $1 / \mathrm{T}^{\circ} \mathrm{K}$ is used to write a new $\mathrm{Na} / \mathrm{K}$ geothermometer described in the text.

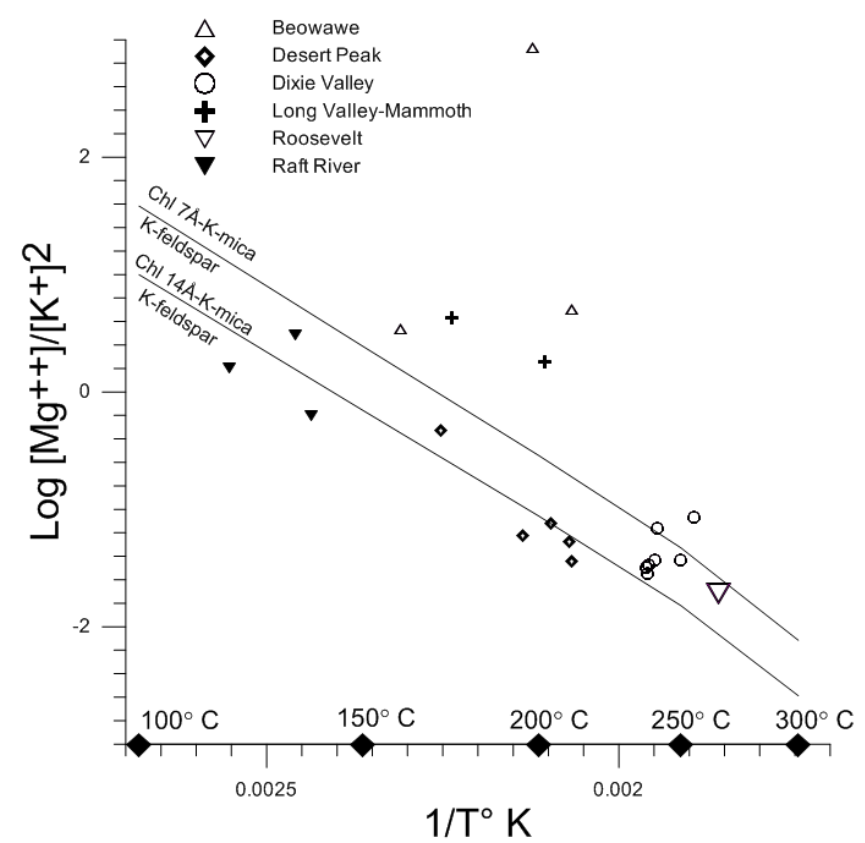

Figure 7. Aqueous compositions of Log $\left[\mathrm{Mg}^{++}\right] /\left[\mathrm{K}^{+}\right]^{2}$ versus temperature (after Giggenbach, 1988). 


\section{Appendix A}

Table 1. Summary water chemistry data from Great Basin geothermal systems; concentration units mg/kg.

\begin{tabular}{|c|c|c|c|c|c|c|c|c|c|c|c|c|c|}
\hline $\begin{array}{l}\text { System/well } \\
\text { Beowawe }\end{array}$ & $\operatorname{Res} / \operatorname{Max} \mathrm{T}^{\circ} \mathrm{C}$ & pH (lab) & Li & $\mathrm{Na}$ & K & $\mathrm{Ca}$ & $\mathbf{M g}$ & $\mathrm{Cl}$ & $\mathbf{F}$ & SO4 & $\mathrm{HCO} 3$ & B & $\mathrm{SiO} 2$ \\
\hline Rossi 21-19 & 198 & 8.10 & 0.90 & 143 & 14.0 & 24.0 & 7.10 & 25 & 2.8 & 28 & 145 & 0.9 & 427 \\
\hline Ginn 1-13 & 211 & 8.40 & 1.40 & 203 & 30.0 & 11.0 & 0.30 & 59 & 7.9 & 47 & 260 & 1.7 & 335 \\
\hline $85-18$ & 160 & 9.10 & 1.90 & 277 & 35.0 & 2.5 & 0.30 & 31 & 18 & 76 & 267 & 2.0 & 436 \\
\hline \multicolumn{14}{|l|}{ Desert Peak } \\
\hline $21-1$ & 204 & 8.29 & 4.00 & 2500 & 251.0 & 114.0 & 0.11 & 4350 & nd & 104 & 38 & 18.2 & \\
\hline $67-21$ & 210 & 8.17 & nd & 3040 & 312.0 & 183.0 & 0.12 & 5350 & nd & 128 & 33 & 20.0 & 3 \\
\hline $77-21$ & 195 & 8.33 & nd & 2990 & 306.0 & 149.0 & 0.13 & 5080 & nd & 121 & 44 & 23.7 & \\
\hline $86-21$ & 211 & 8.18 & nd & 2830 & 324.0 & 148.0 & 0.08 & 5030 & nd & 97 & 32 & 22.6 & 3 \\
\hline $74-21$ & 171 & 8.36 & nd & 3180 & 316.0 & 227.0 & 1.18 & 5670 & nd & 189 & 55 & 21.2 & \\
\hline \multicolumn{14}{|l|}{ Dixie Valley } \\
\hline 76-7 DV96-8 & 255 & 9.09 & 2.29 & 474 & 69.5 & 8.5 & 0.03 & 524 & 13.4 & 201 & 121 & 11.6 & \\
\hline 74-7 DV97 $14+15$ & 238 & 9.06 & 2.43 & 500 & 72.2 & 9.2 & 0.01 & 584 & 13.5 & 204 & 71 & 11.8 & \\
\hline 82a-7 DV97 20+21 & 237 & 9.05 & 2.22 & 495 & 72.6 & 9.6 & 0.01 & 575 & 14.5 & 212 & 125 & 11.7 & \\
\hline 73b-7 DV97 22-23 & 238 & 9.07 & 2.34 & 499 & 76.4 & 9.1 & 0.01 & 571 & 13.7 & 212 & 128 & 11.7 & \\
\hline $27-33$ DV97 $25+27$ & 240 & 9.03 & 2.22 & 423 & 66.8 & 7.7 & 0.01 & 443 & 14.7 & 183 & 184 & 9.2 & 62 \\
\hline 37-33 DV97 28+29 & 241 & 9.16 & 2.26 & 431 & 68.8 & 7.2 & 0.02 & 475 & 16.1 & 191 & 165 & 9.5 & \\
\hline 27-33 Reed '89 & 250 & 9.70 & 2.98 & 438 & 69.7 & 1.0 & 0.01 & 352 & 15.2 & 139 & 454 & 11.9 & \\
\hline \multicolumn{14}{|l|}{ Mammoth-Long Valley } \\
\hline Shady Rest & 202 & 5.90 & 2.80 & 369 & 43.0 & 7.4 & 0.20 & 280 & 12 & 159 & 375 & 12.0 & \\
\hline Casa Diablo MBP-4 & 174 & 6.00 & nd & 350 & 36.0 & 6.9 & 0.24 & 230 & 10 & 110 & 440 & 10.0 & \\
\hline \multicolumn{14}{|l|}{ Roosevelt } \\
\hline $14-2$ & 265 & 6.20 & 2.26 & 2200 & 410.0 & 6.9 & 0.08 & 3650 & 4.8 & 60 & 170 & 28.0 & \\
\hline \multicolumn{14}{|l|}{ Raft River } \\
\hline RRG-1 & 137 & 7.19 & 1.89 & 670 & 83.2 & 56.2 & 0.11 & 1181 & 7.07 & 62.1 & 40 & 0.5 & \\
\hline RRG-4 & 134 & 7.50 & 1.92 & 537 & 43.5 & 50.8 & 0.15 & 833 & 7.3 & 59.2 & 66 & 0.5 & \\
\hline RRG-7 & 119 & 700 & 4.44 & 1610 & 158.0 & 217.0 & 0.90 & 3000 & 474 & 59.3 & 33 & 0.6 & \\
\hline
\end{tabular}

Source

Cole \& Ravinsky, 1984 Cole \& Ravinsky, 1984 Cole \& Ravinsky, 1984

BM Kennedy (unpublished LBNL data) BM Kennedy (unpublished LBNL data) BM Kennedy (unublished LBNL data) BM Kennedy (unpublished BM Kennedy (unpublished LBNL data)

Goff et al., 2002 Goff et al., 2002 Goff et al., 2002 Goff et al., 2002 Goff et al., 2002 Goff et al., 2002 Reed, 1989

Tempel et al., 2011 Tempel et al., 201

Capuano \& Cole, 1982

B Ayling \& J Moore (in press) B Ayling \& J Moore (in press) B Ayling \& J Moore (in press) 
Table 2. Summary gas chemistry data from Desert Peak and Dixie Valley geothermal systems; concentration units mole percent.

\begin{tabular}{|c|c|c|c|c|c|c|c|c|c|c|c|c|c|}
\hline $\begin{array}{l}\text { System/well } \\
\text { Desert Peak }\end{array}$ & $\operatorname{Res} / \operatorname{Max} \mathrm{T}^{\circ} \mathrm{C}$ & $\mathrm{H}(\mathrm{kJ} / \mathrm{kg})$ & SF (collection) & steam/gas molar & $\mathrm{CO} 2$ & $\mathrm{H} 2 \mathrm{~S}$ & $\mathrm{CH} 4$ & N2 & NH3 & H2 & $\mathrm{He}$ & Ar & Source \\
\hline $21-1$ & 204 & 873 & 0.12 & 1175 & 91.5 & 0.81 & 0.50 & 5.61 & 1.49 & 0.157 & nd & 0.108 & BM Kennedy (unpublished LBNL data) \\
\hline $67-21$ & 210 & 898 & 0.15 & 1908 & 86.7 & 1.07 & 0.27 & 10.90 & 0.95 & 0.348 & nd & 0.160 & BM Kennedy (unpublished LBNL data) \\
\hline $77-21$ & 195 & 830 & 0.11 & 1502 & 87.2 & 1.73 & 0.48 & 9.31 & 1.11 & 0.180 & nd & 0.153 & BM Kennedy (unpublished LBNL data) \\
\hline $86-21$ & 211 & 902 & 0.15 & 1695 & 85.0 & 2.21 & ,336 & 11.20 & 1.06 & 0.225 & nd & 0.168 & BM Kennedy (unpublished LBNL data) \\
\hline \multicolumn{14}{|l|}{ Dixie Valley } \\
\hline 76-7 DV96-8 & 255 & 1109 & 0.18 & 604 & 97.5 & 0.56 & 0.46 & 0.80 & 0.69 & 0.013 & nd & 0.013 & Goff et al., 2002 \\
\hline 74-7 DV97 14+15 & 238 & 1029 & 0.16 & 542 & 96.8 & 0.74 & 0.57 & 0.97 & 0.41 & 0.015 & nd & 0.054 & Goff et al., 2002 \\
\hline 82a-7 DV97 20+21 & 237 & 1023 & 0.16 & 540 & 93.9 & 1.09 & 0.80 & 3.64 & 0.54 & 0.018 & nd & 0.058 & Goff et al., 2002 \\
\hline 27-33 DV97 25+27 & 240 & 1036 & 0.16 & 376 & 95.2 & 0.93 & 1.02 & 2.22 & 0.53 & 0.031 & nd & 0.045 & Goff et al., 2002 \\
\hline 37-33 DV97 28+29 & 241 & 1040 & 0.16 & 448 & 94.5 & 1.20 & 0.59 & 3.06 & 0.56 & 0.025 & nd & 0.055 & Goff et al., 2002 \\
\hline 27-33 Reed '89 & 250 & 1086 & 0.18 & $?$ & 97.0 & 0.86 & 0.35 & 1.50 & 0.21 & 0.010 & 0.037 & 0.026 & Reed, 1989 \\
\hline
\end{tabular}

Table 3. Comparison of computed outputs of activity coefficients (gammas) and activities (log values) for 4 water analyses (Desert Peak and Dixie Valley) using WATCH and SOLVEQ. pH values from WATCH were used in SOLVEQ calculations. Concentrations (log molal units) are based on data from Table 1.

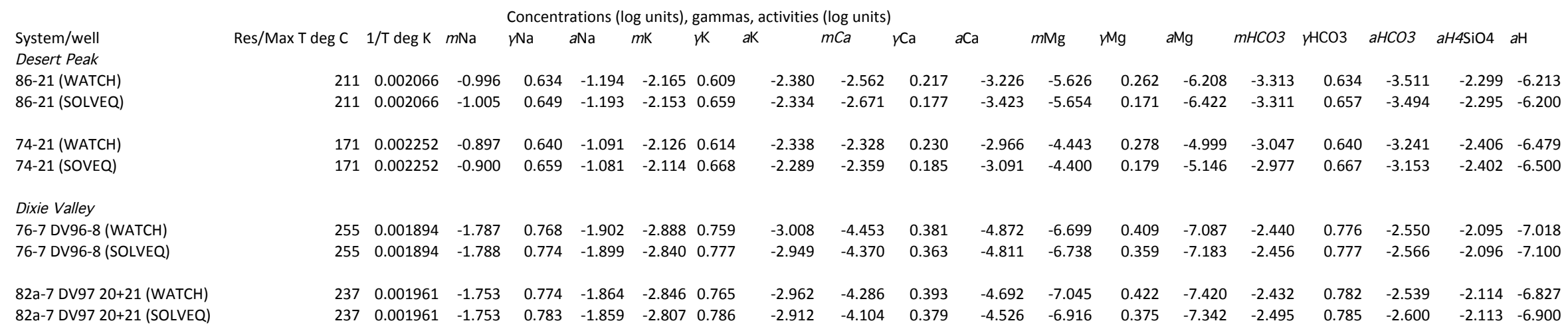




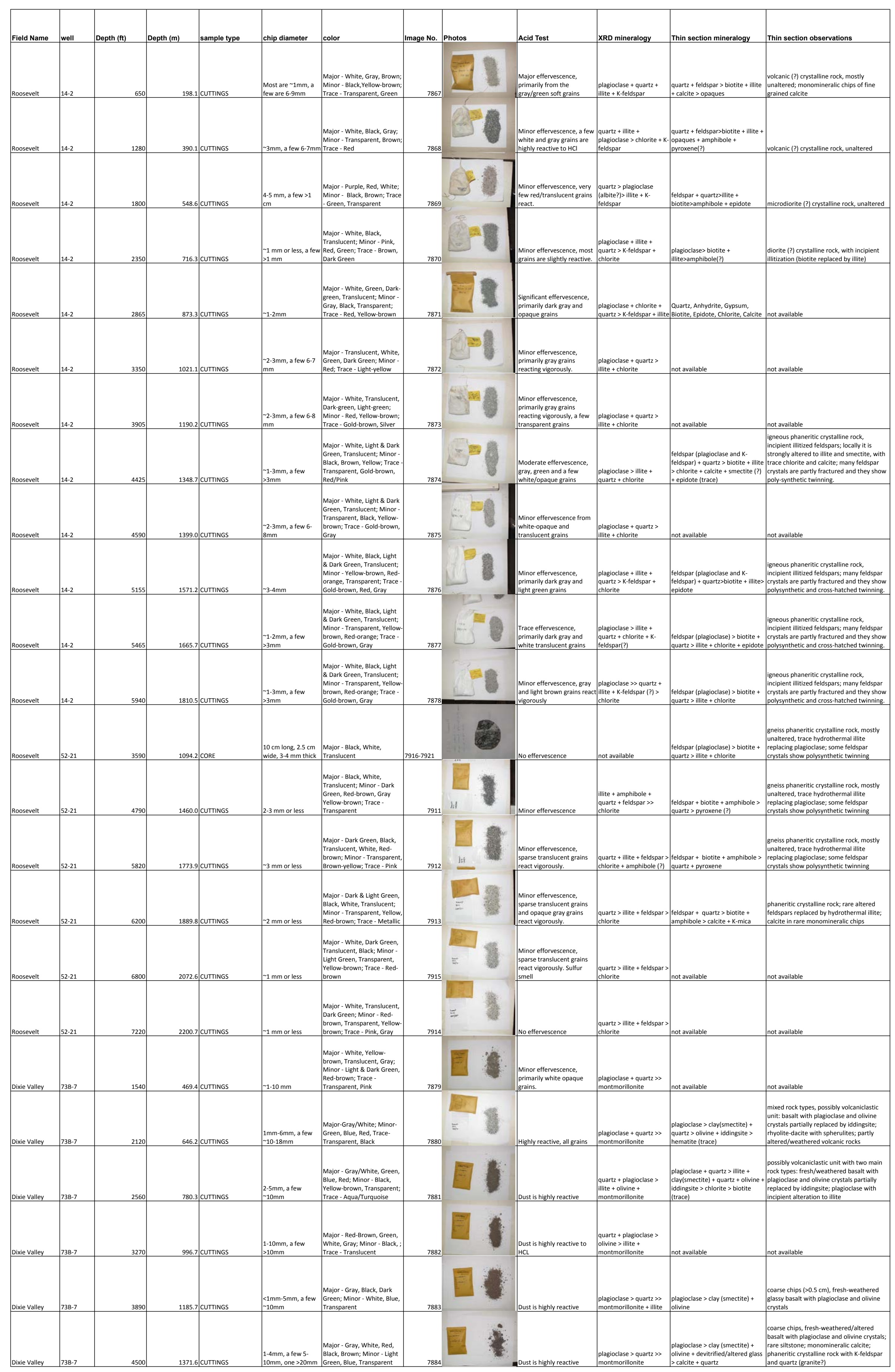




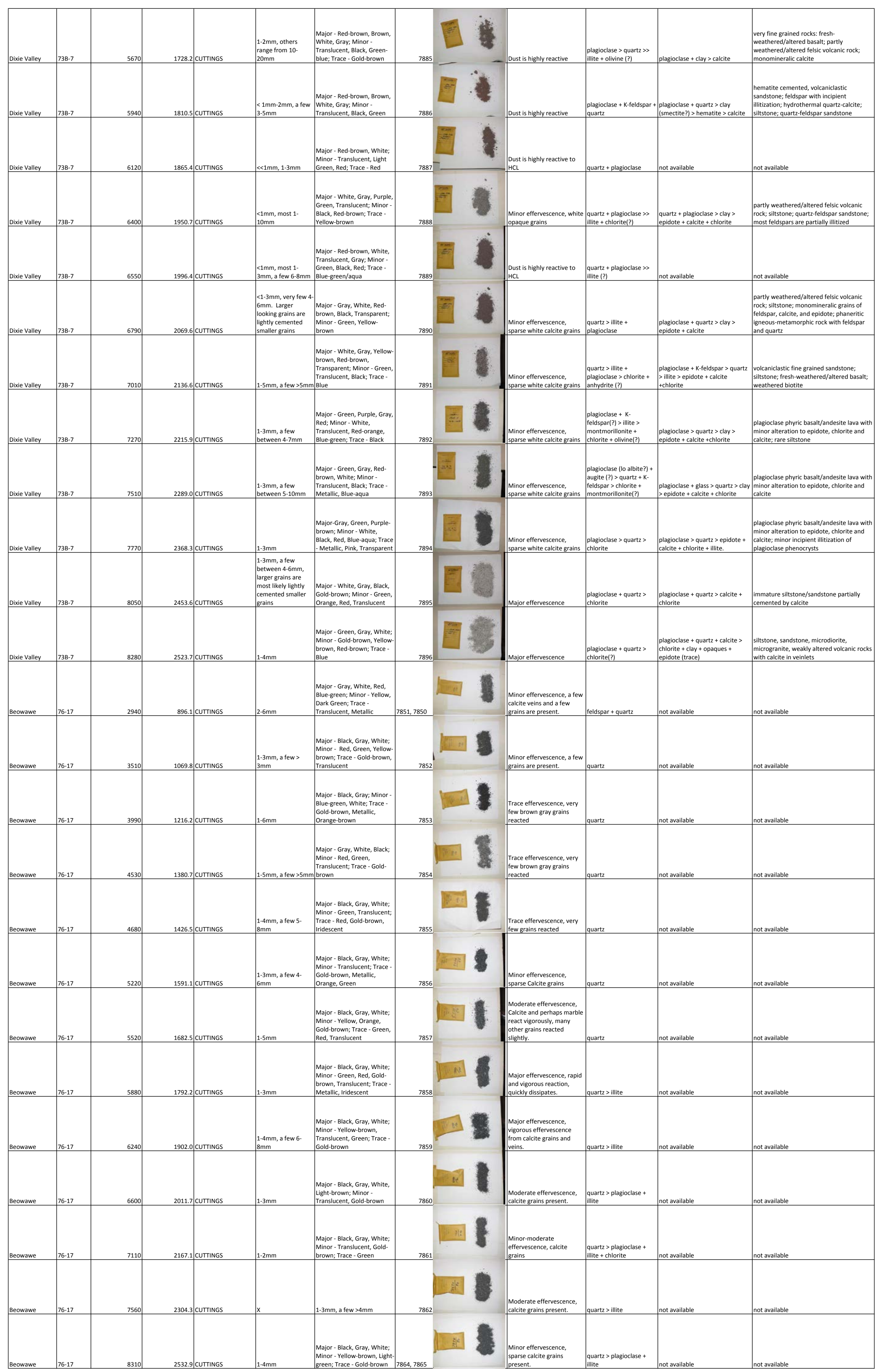




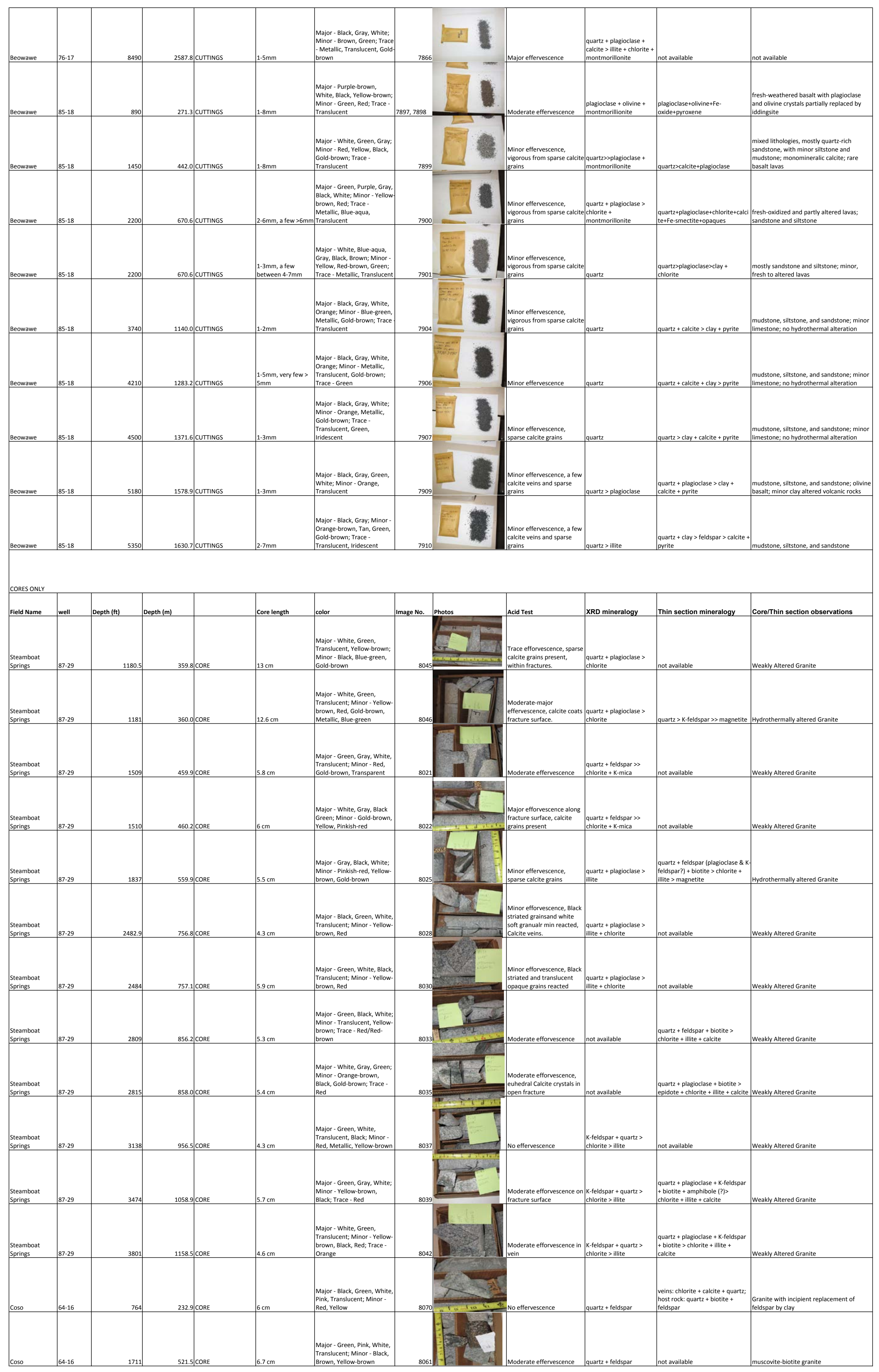




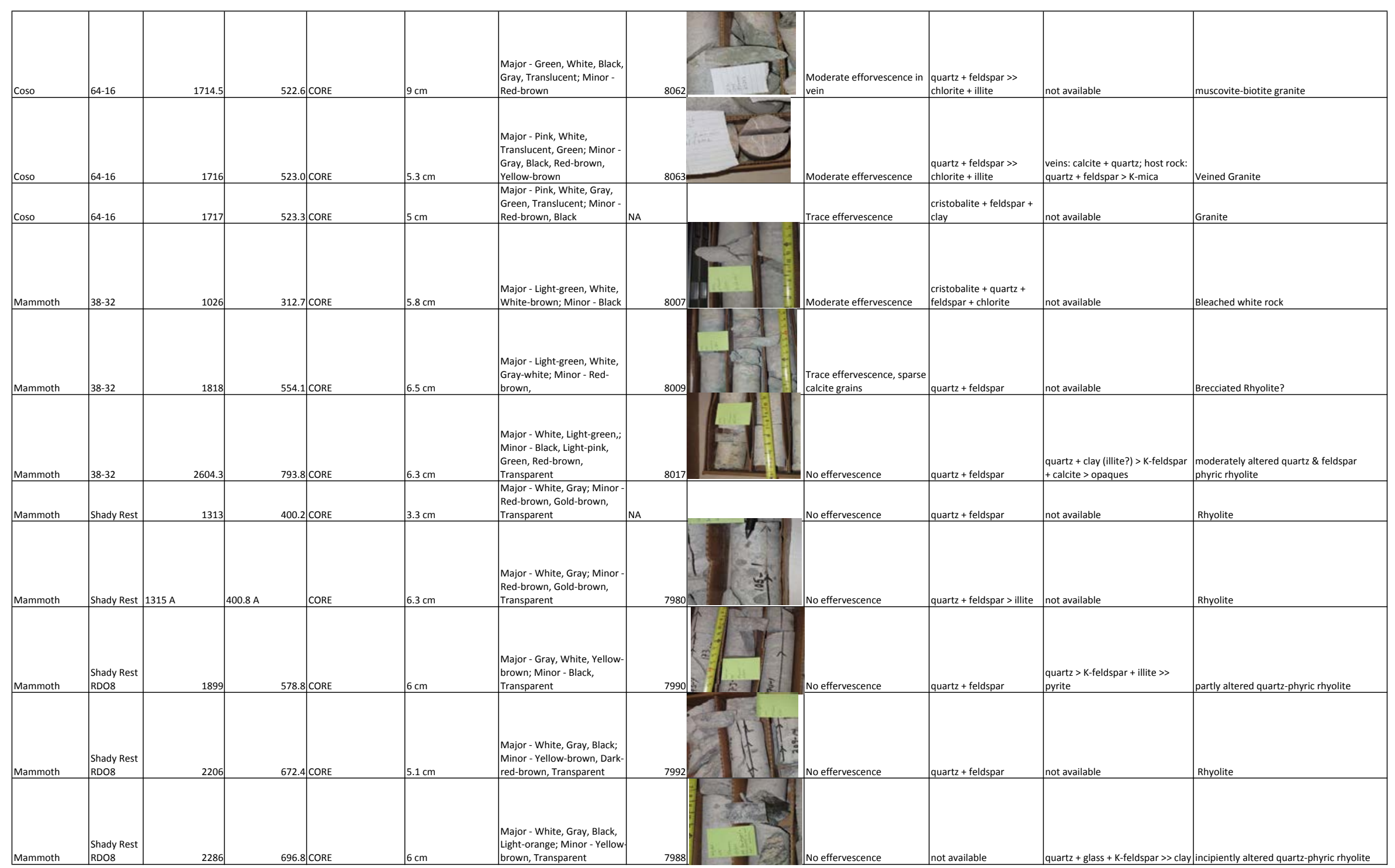




\title{
Thermal-Hydrological-Chemical Model for the Desert Peak Geothermal System
}

\author{
E.L. Sonnenthal, N.F. Spycher, P.F. Dobson, and B.M. Kennedy
}

\section{Introduction}

To investigate the effects of reaction paths on fluid compositions and fluid-mineral equilibria, a thermal-hydrological-chemical (THC) model of a localized region of the Desert Peak Geothermal area was developed to quantify the effects (i.e, water-rock interaction, fluid mixing, and cooling) that can modify water compositions in the shallow subsurface. Uncertainties in geothermometric temperatures calculated for thermal fluids sampled near the surface are a function of many effects, as documented for the Dixie Valley Geothermal System (Wanner et al., 2013).

The main tasks in the first phase of this project are as follows:

1. Create a two-dimensional numerical mesh and thermal-hydrological model of the Desert Peak Geothermal Field incorporating primary structural and lithologic features, including permeabilities and fracture densities.

2. Simulate the primary fluid flow pathways and temperature distributions.

3. Incorporate primary and secondary mineral distributions as determined from well logs with respective thermodynamic and kinetic data, and available experimental data.

4. Simulate the coupled THC system with comparison to measured deep fluid compositions at various depths and in different host rocks.

5. Assess results using multicomponent chemical geothermometry with evaluation of effects due to transport, mixing and reaction. Assess effectiveness of multicomponent geothermometry to predict temperatures in different reservoir rocks and thermal-hydrological regimes.

The THC model for Desert Peak differs from the THM reservoir-type models (Sharad, Benato) that have been used to evaluate stimulation during injection at Desert Peak and studies of tracer transport during injection/production, because of the detail needed for description of geological, lithologic, and larger-scale thermal-hydrologic structure of the system. It starts with locally-refined thermal-hydrological models similar to those described by McKenna and Blackwell (2004) and Wisian and Blackwell (2004) that encompass near-surface to sub-reservoir depths, then adding more levels of detail into parameters required to evaluate the water-gas-rock reactions that take place over a wide range of time scales. The following sections describe the model development and preliminary inputs. It should be noted that model development follows an iterative procedure, with each iteration leading to refinement of specific aspects of the geothermal system as warranted, or for sensitivity testing. The parameters and inputs will change as the model is further developed and new data are incorporated.

Simulations were performed using TOUGHREACT V2.2G (Sonnenthal et al., in prep), a new parallelized version of TOUGHREACT V2 (Xu et al., 2011) with additional features for large meshes and geothermal modeling, including temperature and compositiondependent heat capacities and thermal conductivities.

\section{Geologic Model}


A detailed geologic summary and history of the initial geothermal exploration and development at Desert Peak is found in Benoit et al. (1982). More recent work associated with EGS development at Desert Peak has led to several recent studies of the structure, fluid flow, and mineralogy (e.g., Lutz et al., 2009, 2010, 2011; Hickman \& Davatzes, 2010; Rose et al., 2009; Faulds et al. 2010, 2012). Most of the data used for the development of the Desert Peak THC Model were derived from the latter sources.

A north-south cross section (Figure 1) of the geothermal field was presented by Lutz et al. (2009) and further modified by Hickman \& Davatzes (2010). The lithologic and mineralogical distributions presented by Lutz et al. $(2009,2010,2011)$ were used as a basis for the development of a reaction-transport model of the field. A more recent geologic map (Figure 2; Faulds et al., 2012) and E-W cross-section (Figure 3; Faulds et al., 2012) shows a more detailed representation of the geologic units and a different interpretation of the fault geometry (faults extend to surface).

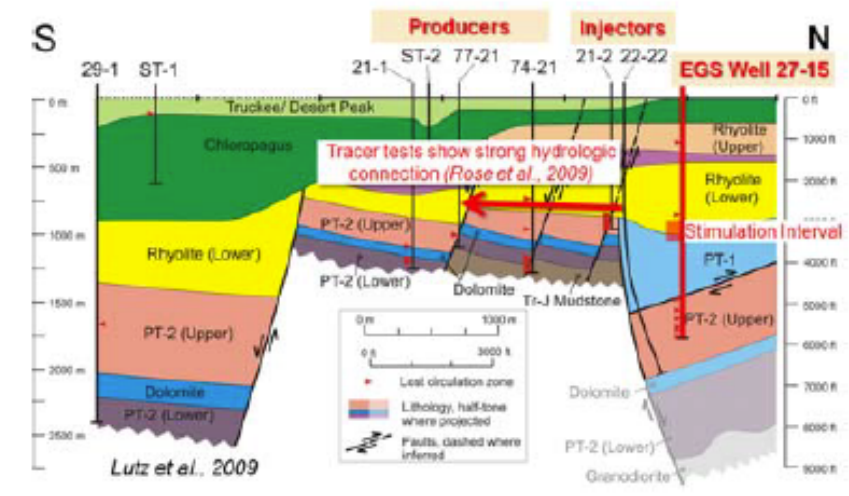

Figure 1. North-South cross-section of Desert Peak Geothermal System (Hickman \& Davatzes, 2010, modified from Lutz et al., 2009).

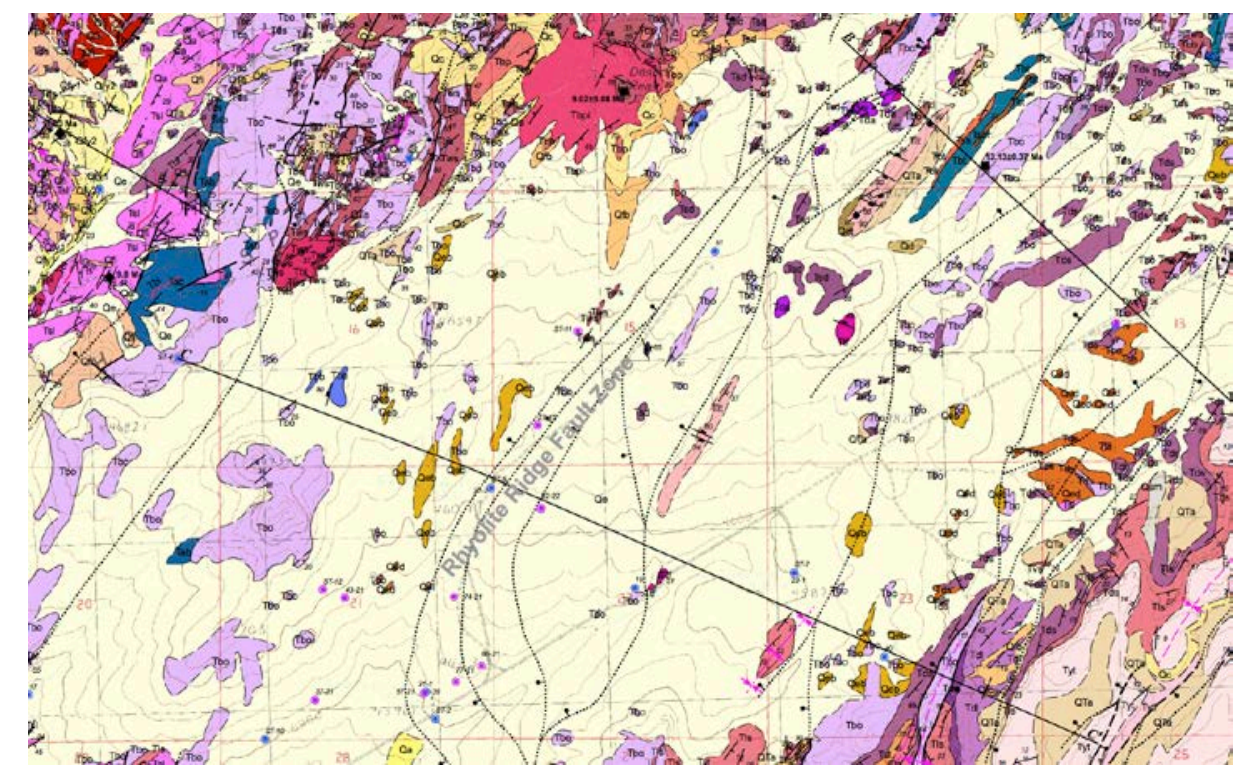


Figure 2. Cutout of Preliminary Geologic map of Dixie Valley Geothermal Area (Faulds et al., 2012), showing C-C' cross-section through Rhyolite Ridge Fault System and region of dilation.

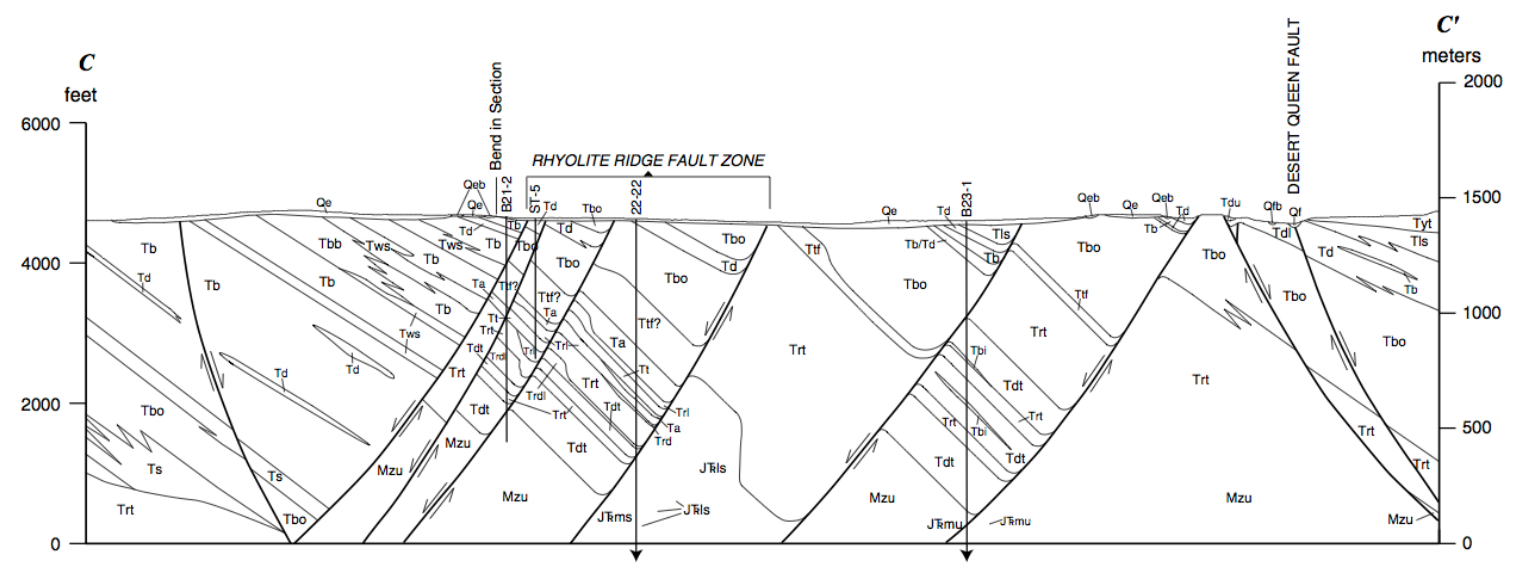

Figure 3. C-C' cross-section through Rhyolite Ridge Fault System (Faulds et al., 2012).

\section{Two-Dimensional Numerical Grid of Rhyolite Ridge Fault System}

The numerical grid was developed by digitizing a region approximately $2.5 \mathrm{~km}$ wide $\times 1.4$ $\mathrm{km}$ in depth from the C-C' cross-section shown in Figure 3. Grid block centers were then overlain on the digitized geologic map and rock units assigned using based on their location within a closed polygon describing each stratigraphic layer.

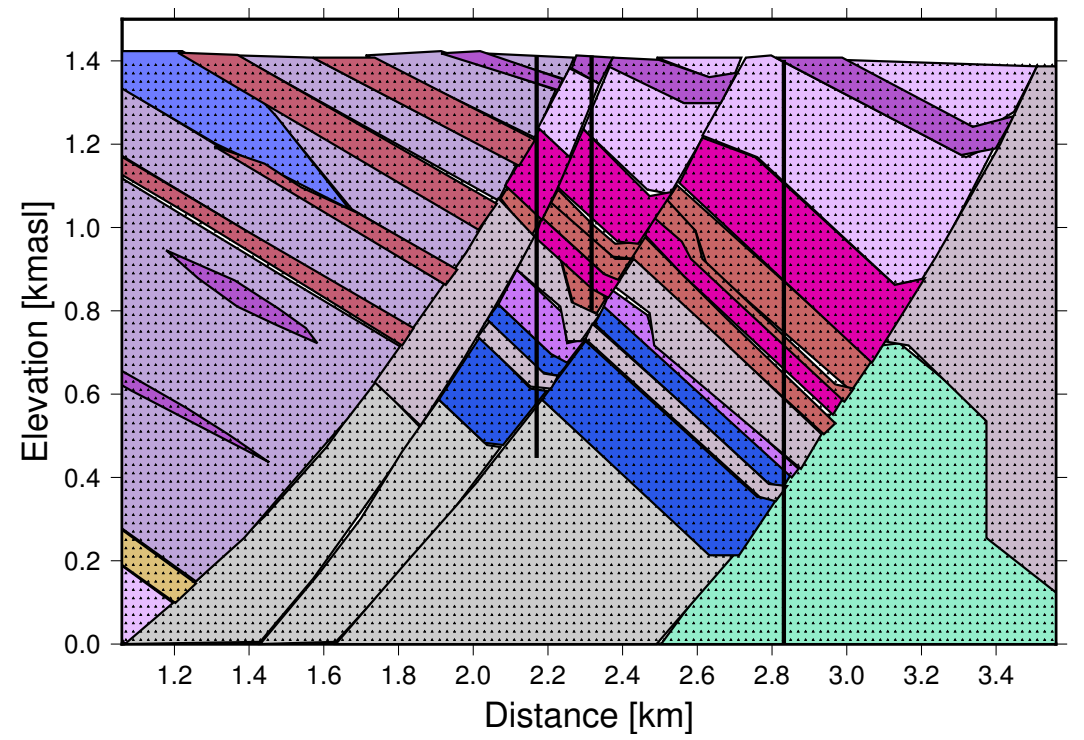

Figure 4. Digitized contacts of main units and faults from cross-section shown in Figure 3 with numerical grid block centroids overlain.

The $20 \times 20 \mathrm{~m}$ grid blocks with their unique geologic properties are shown in Figure 5 . Faults are shown as discontinuities in the geologic structure, with no physical dimension; however their hydrological representation can be done in several ways based on the conceptual model for the fault permeability and fracture characteristics. 


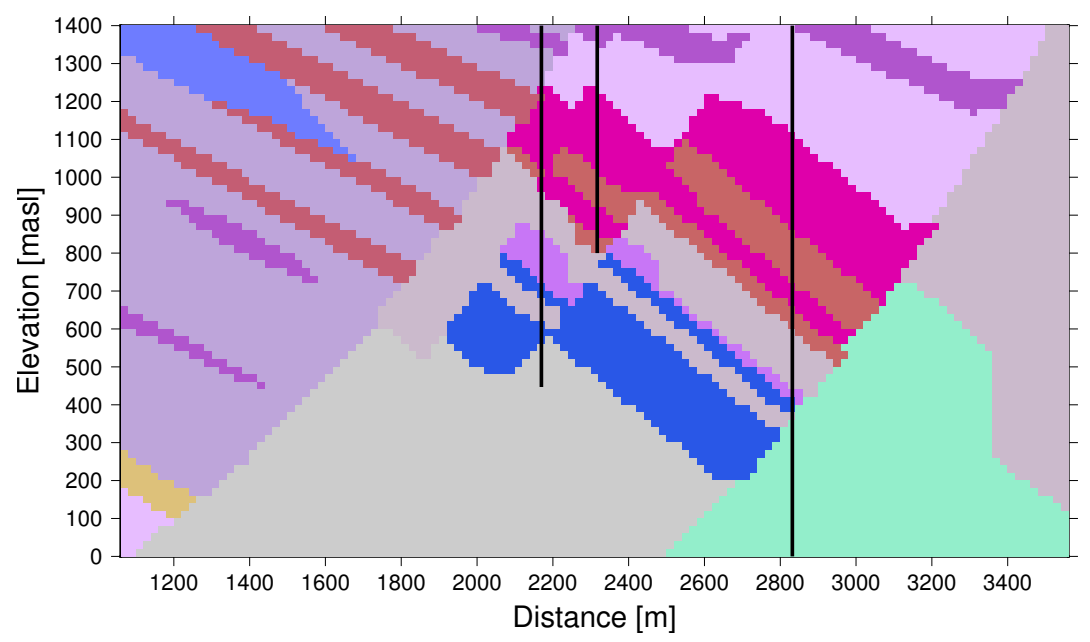

Figure 5. TOUGHREACT grid blocks with assigned hydrological/mineralogical and thermal properties.

In order to capture the fluid flow and reactive pathways through the faults and fractured rocks with differing fracture spacing, connectivity, and mineral properties, the grid was extended to consider a dual-permeability model for reactive transport as shown schematically in Figure 5. (as in Sonnenthal et al., 2005).

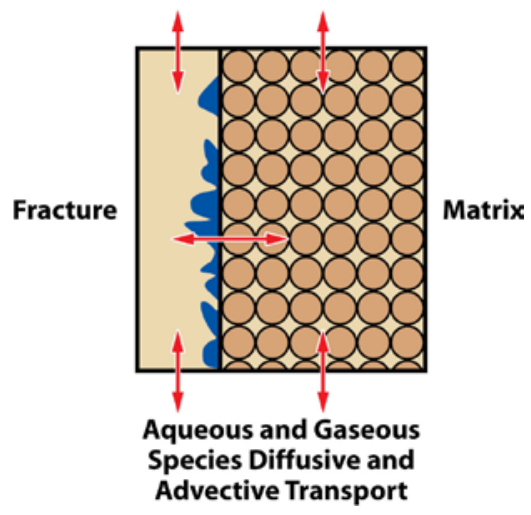

Figure 6. Dual Permeability Concept for Reactive Transport in Fractured Rock

\section{Thermal-Hydrological Model Parameters}

A preliminary set of thermal-hydrological parameters is shown in Table 1, derived from data in the Lutz et al., $(2009,2010,2011)$ papers where available. Other data were estimated or calculated based on similar lithologies.

Table 1. Preliminary Hydrological and Thermal Properties for Lumped Units

\begin{tabular}{|l|c|c|c|c|c|}
\hline \multicolumn{1}{|c|}{ Hydrogeologic Unit } & Porosity & $\begin{array}{c}\text { Permeability } \\
\left(\mathbf{m}^{\mathbf{2}} \mathbf{)}\right.\end{array}$ & $\begin{array}{c}\text { Thermal Cond. } \\
\text { Parameters } \\
(\mathbf{W} / \mathbf{m ~ K})^{\mathbf{1}}\end{array}$ & Tortuosity & $\begin{array}{c}\text { Grain } \\
\text { Density } \\
\left(\mathrm{kg} / \mathrm{m}^{\mathbf{3}}\right)\end{array}$ \\
\hline Tertiary Chloropagus & 0.0904 & $1.0 \times 10^{-18}$ & & 0.20 & \\
\hline
\end{tabular}




\begin{tabular}{|l|c|c|c|c|c|}
\hline basalts, andesites & $0.01(\mathrm{f})$ & $1.0 \times 10^{-16}(\mathrm{f})$ & $474,1.18$ & 0.80 (f) & 2712 \\
\hline Tertiary diatomites \& & 0.2072 & $1.3 \times 10^{-17}$ & & 0.20 & \\
siltstones & $0.01(\mathrm{f})$ & $1.3 \times 10^{-16}(\mathrm{f})$ & 1.00 (fixed) & 0.80 (f) & 2650 \\
\hline Rhyolites \& dacitic rocks & 0.1137 & $1.3 \times 10^{-17}$ & & 0.20 & \\
(lavas \& tuffs) & $0.01(\mathrm{f})$ & $1.3 \times 10^{-16}(\mathrm{f})$ & $807,0.64$ & 0.80 (f) & 2619 \\
\hline Mesozoic metasediments/ & 0.079 & $1.3 \times 10^{-17}$ & & 0.20 & \\
metavolcanics & & $1.3 \times 10^{-16}(\mathrm{f})$ & $705, \quad 0.75$ & 0.80 (f) & 2730 \\
\hline Jurassic limestones & 0.05 & $1.3 \times 10^{-17}$ & & 0.20 & \\
& $0.01(\mathrm{f})$ & $1.3 \times 10^{-16}(\mathrm{f})$ & $1073,0.13$ & $0.80(\mathrm{f})$ & 2619 \\
\hline
\end{tabular}

${ }^{1}$ Parameters A \& B in $k(T)=A /(350+T(C))+B$ (Vosteen and Schellschmidt, 2003)

The initial basal heat flux was assumed to be a spatially uniform $90 \mathrm{~mW} / \mathrm{m}^{2}$ (McKenna \& Blackwell, 2004), with the surface temperature fixed at 12C. The pressure at the surface was set to 0.85 bar, approximately the atmospheric pressure at $1400 \mathrm{~m}$ elevation.

\section{Geochemical Model Inputs}

The preliminary set of primary and secondary minerals were based on the Lutz et al. studies, and are shown in Table 2. Mineral abundances in the basalts and limestones were estimated, while data for the other units are averages. Fracture and matrix mineral abundances were initially assumed to be the same.

Table 2. Preliminary Primary and Secondary Mineral Abundances

\begin{tabular}{|l|l|l|l|l|l|}
\hline Mineral & Chlorop. & Diatom. & Rhyolite $^{1}$ & Metased. $^{2}$ & Limestone \\
\hline Calcite & & & & & \\
\hline Siderite & 0.02 & 0.00 & 0.025 & 0.0183 & 0.75 \\
\hline Ankerite & 0.00 & 0.00 & 0.00 & 0.00 & 0.00 \\
\hline Dolomite & 0.00 & 0.00 & 0.00 & 0.0033 & 0.00 \\
\hline Ab80An20-hi & 0.01 & 0.00 & 0.0125 & 0.0133 & 0.20 \\
\hline Ab40An60-hi & 0.10 & 0.00 & 0.105 & 0.0967 & 0.00 \\
\hline Albite-lo & 0.00 & 0.00 & 0.00 & 0.00 & 0.00 \\
\hline Microcline & 0.00 & 0.00 & 0.00 & 0.14 & 0.00 \\
\hline Sanidine-hi & 0.01 & 0.00 & 0.1225 & 0.0333 & 0.00 \\
\hline Quartz & 0.01 & 0.00 & 0.485 & 0.00 & 0.00 \\
\hline Cristobalite & 0.00 & 1.00 & 0.00 & 0.00 & 1.00 \\
\hline Amor. Silica & 0.00 & 0.00 & 0.00 & 0.00 & 0.00 \\
\hline Chalcedony & 0.00 & 0.00 & 0.00 & 0.00 & 0.00 \\
\hline Diopside & 0.15 & 0.00 & 0.00 & 0.00 & 0.00 \\
\hline Hedenbergite & 0.15 & 0.00 & 0.00 & 0.00 & 0.00 \\
\hline Annite & 0.00 & 0.00 & 0.00 & 0.00 & 0.00 \\
\hline Phlogopite & 0.00 & 0.00 & 0.00 & 0.00 & 0.00 \\
\hline Muscovite & 0.00 & 0.00 & 0.00 & 0.00 & 0.00 \\
\hline Daphnite & 0.00 & 0.00 & 0.005 & 0.0459 & 0.00 \\
\hline Clinochlore & 0.00 & 0.00 & 0.005 & 0.0459 & 0.00 \\
\hline Epidote & 0.00 & 0.00 & 0.00 & 0.00 & 0.00 \\
\hline Illite & 0.00 & 0.00 & 0.154 & 0.1433 & 0.00 \\
\hline Nontronite-Mg & 0.001 & 0.00 & 0.0156 & 0.0433 & 0.00 \\
\hline
\end{tabular}




\begin{tabular}{|l|l|l|l|l|l|}
\hline Nontronite-Ca & 0.001 & 0.00 & 0.0156 & 0.0433 & 0.00 \\
\hline Nontronite-Na & 0.001 & 0.00 & 0.0156 & 0.0433 & 0.00 \\
\hline Nontronite-K & 0.001 & 0.00 & 0.0156 & 0.0433 & 0.00 \\
\hline Kaolinite & 0.00 & 0.00 & 0.0025 & 0.0183 & 0.00 \\
\hline Laumontite & 0.00 & 0.00 & 0.00 & 0.00 & 0.00 \\
\hline Clinoptilolite-Na & 0.001 & 0.00 & 0.00 & 0.00 & 0.00 \\
\hline Clinoptilolite-K & 0.001 & 0.00 & 0.00 & 0.00 & 0.00 \\
\hline Analcite & 0.001 & 0.00 & 0.00 & 0.00 & 0.00 \\
\hline Goethite & 0.00 & 0.00 & 0.00 & 0.00 & 0.00 \\
\hline Hematite & 0.001 & 0.00 & 0.00 & 0.03 & 0.00 \\
\hline Magnetite & 0.05 & 0.00 & 0.0075 & 0.005 & 0.00 \\
\hline Pyrite & 0.00 & 0.00 & 0.0125 & 0.02 & 0.00 \\
\hline Fluorapatite & 0.01 & 0.00 & 0.00 & 0.0133 & 0.00 \\
\hline
\end{tabular}

${ }^{1}$ Average of XRD abundances for Tertiary rhyolites from 27-15 well core reported by Lutz et al. (2009).

${ }^{2}$ Average of XRD abundances for Mesozoic metavolcanics and metasediments from 2715 well core reported by Lutz et al. (2009).

The initial water chemistry for the preliminary simulation was a groundwater composition from similar volcanic rocks at Newberry, Volcano in Oregon (Sonnenthal et al., 2012). As the model is updated, waters from specific areas in Desert Peak will be introduced to looking at mixing as well as reaction trends.

\section{Simulation Results}

Preliminary simulations were performed for the full system for about 2300 years of reaction time. Multicomponent geothermometry (Spycher et al., 2011) and elementspecific geothermometers were used on specific output water compositions to evaluate the degree of equilibration in this kinetic system undergoing temperature increase over time owing to the basal heat flux input.

Looking at the trends in mineral alteration in space gives important insight into the system evolution reflecting effects of spatial and temporal variations in fluid chemistry, transport and lithologic variations. Such variations are factors that control changes in fluid chemistry as thermal water are transported through different lithologic units towards the surface. Whereas the model system has 36 minerals, here we plot just four minerals in Figure 7 to look at changes that may exert a major control on fluid chemistry (quartz, kaolinite, clinochlore, and calcite). All plots show mineral abundance changes in moles per $\mathrm{m}^{3}$ of total volume of rock (rock + fluid) and are for alteration in fractures. 

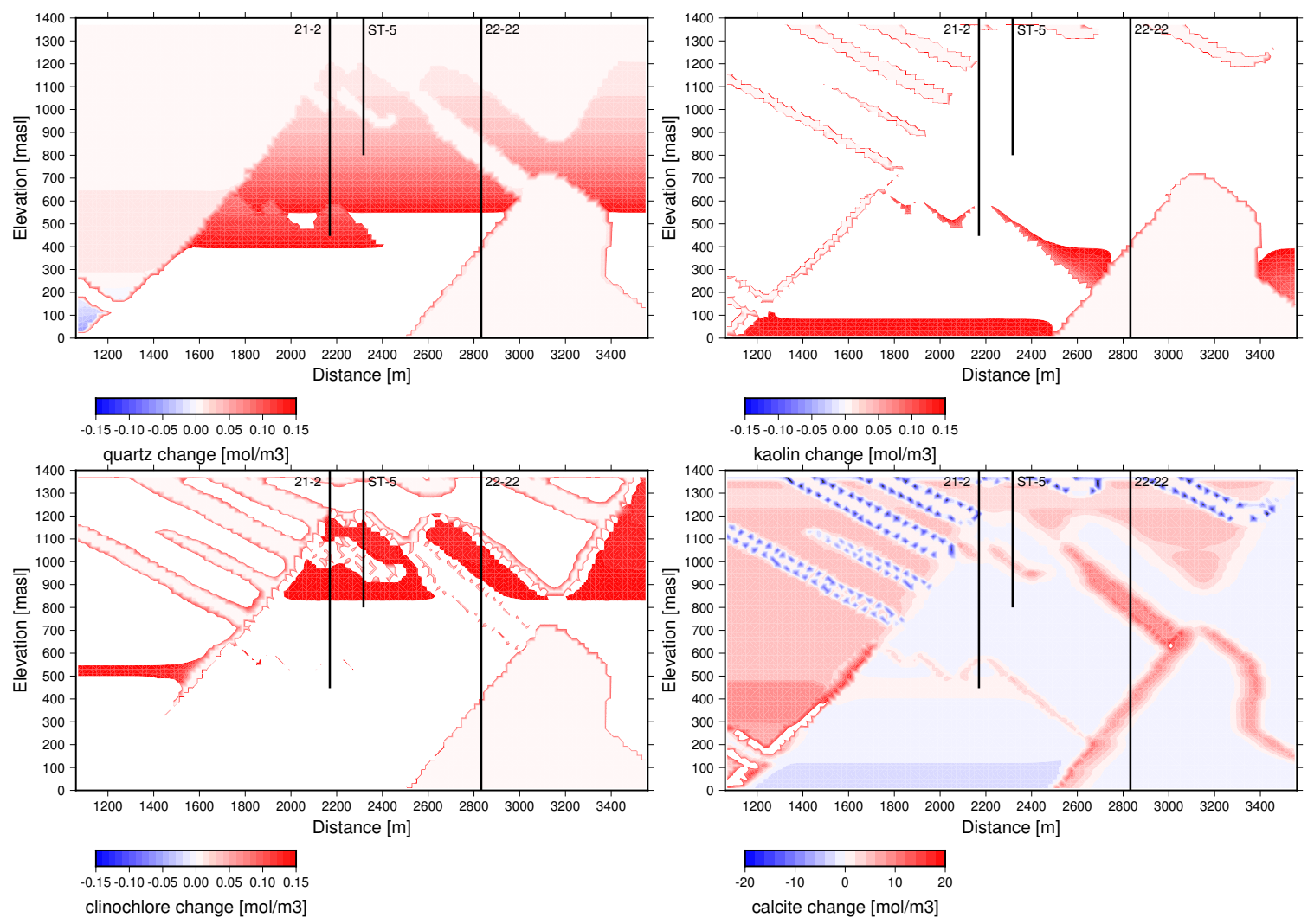

Figure 7. Change in mineral abundances (moles mineral $/ \mathrm{m}^{3}$ of rock) over 1000 years. Wells are plotted as black lines. Spotty regions of dissolution/precipitation are contouring artifacts.

The distribution of changes in quartz abundance clearly show variations due to initial lithology and also increasing precipitation of quartz with depth in specific units. However, near the base of the system, quartz is either close to equilibrium thoughout the simulation or dissolving in the deepest rhyolitic unit at the western boundary. Also note that contrasts in lithology at stratigraphic contacts and fault boundaries show pervasive quartz precipitation.

Kaolinite clearly shows greater precipitation at depth at boundaries as well. The distribution of alteration though, is not simply a function of depth, temperature, or lithology, as alteration is often where mixing of fluids of fluids reacting with different mineral assemblages takes place.

Clinochlore precipitation is greatest in the basaltic units, where even though the temperature is lower there is much more $\mathrm{Mg}$ (from pyroxene dissolution) than in the rhyolites.

Calcite shows the most interesting behavior as many factors control its reactivity $-\mathrm{pH}$, $\mathrm{PCO}_{2}$, temperature, and alteration of plagioclase and clinopyroxene. Along faults there are thick zones of calcite precipitation particularly on the higher temperature lower side of the fault. Precipitation is strong even adjacent to units that are showing net calcite dissolution, and vice-versa. 


\section{Conclusions and Phase II Planned Work}

Development of a model that can capture the transient behavior of a geothermal system from near-surface recharge to deep heat flow and fluid migration along permeable pathways and faults, requires a systematic evaluation of hydrological, thermal, mineralogical, geochemical, and isotopic data for a large complex geologic system. Once a model is developed and populated with representative parameters at the necessary spatial resolution, the model becomes a powerful laboratory to test hypotheses regarding the evolution of geothermal fluids. Here we have developed a preliminary dual-permeability thermal-hydrological-chemical model of a region of the Desert Peak Geothermal system to evaluate the role of different factors in changing fluid compositions such that exploration of hidden systems through analysis of shallower thermal waters can be interpreted more quantitatively.

While the results are just a preliminary snapshot of the detailed output of the thermalhydrogical-chemical model, further work will look at the details of different fluids migrating, mixing, and reacting along pathways in the system from greater depths and their changes as they near the surface. Multicomponent and elemental geothermometry are being and will be more systematically tested on the simulated waters with specific knowledge of their temperature evolution, migration pathways, mixing and reaction history. This will allow evaluation of the efficacy of geothermometers in determining reservoir temperatures and initial mineral equilibration assemblages. In Phase II we will also continue the development of the database for Desert Peak water and mineral chemistries as well as hydrological properties such that the simulations are more representative of the geothermal system.

We can then look at regions of the system that may be reached with shallow wells, which would most likely retain fluid compositions characteristic of high-temperature geothermal reservoir fluids. It is clear from the numerical modeling results, that it may not be simply a function of temperature or lithology but instead specific pathways and how fluid reflects the contrasts in reactions taking place in adjacent lithologies.

\section{References}

Benoit, W.R., Hiner, J.E., and Forest, R.T., 1982. Discovery and geology of the Desert Peak geothermal field: A case history: Nevada Bureau of Mines and Geology Bulletin 97, $82 \mathrm{p}$.

Hickman S. and Davatzes, N. (2010). In-situ stress and fracture characterization for planning of an EGS stimulation in the Desert Peak geothermal field, Nevada, PROCEEDINGS, Thirty-Fifth Workshop on Geothermal Reservoir Engineering Stanford University, Stanford, California, February 1-3, 2010 SGP-TR-188.

Faulds, J.E., Ramelli, A.R., Garside, L.J., Coolbaugh, M.F., and Green H., 2012. Preliminary Geologic Map of the Desert Peak Quadrangle, Churchill County, Nevada. Nevada Bureau of Mines and Geology, University of Nevada, Reno.

Faulds, J.E., Coolbaugh, M.F., Benoit, D., Opplinger, G., Perkins, M., Moeck, I., and Drakos, P., 2010. Structural controls of Geothermal Activity in the Northern Hot springs Mountains, Western Nevada: the tale of three Geothermal systems (Brady's, Desert Peak, and Desert Queen). GRC Transactions, 34: 675-683. 
Lutz, S.J., Zutshi A., Robertson-Tait, A., Drakos, P., and Zemach, E., 2011. Lithologies, hydrothermal alteration, and rock mechanical properties in Wells 15-12 and BCH-3, Bradys Hot Springs Geothermal Field, Nevada. GRC Transactions, 35: 469-476.

Lutz, S.L., Hickman, S., Davatzes, N., Zemach, E., Drakos, P., and Robertson-Tait, A., 2010. Rock mechanical testing and petrologic analysis insupport of well stimulation activities at the Desert Peak Geothermal Field, Nevada, Proceedings 35thWorkshop on Geothermal Reservoir Engineering, Stanford Univ., Stanford, CA, SGP-TR-188.

Lutz, S., Moore, J., Jones, C., Suemnicht, G., and Robertson-Tait, A. (2009), Geological and structural relationships in the Desert Peak Geothermal System, Nevada: Implications for EGS development, Proceedings 34th Workshop on Geothermal Reservoir Engineering, Stanford Univ., Stanford, CA, SGP-TR-187.

McKenna, J.R., Blackwell, D.D., 2004. Numerical modeling of transient Basin and Range extensional geothermal systems. Geothermics 33 (4), 457-476.

Rose, P., Leecaster, K., Drakos, P., and Robertson- Tait, A., 2009. Tracer testing at the Desert Peak EGS Project. Geothermal Resources Council Transactions, 33:241-244.

Sonnenthal E., N. Spycher, O. Callahan, T. Cladouhos, and S. Petty. A thermalhydrological-chemical model for the Enhanced Geothermal System Demonstration Project at Newberry Volcano, Oregon. PROCEEDINGS, Thirty-Seventh Workshop on Geothermal Reservoir Engineering Stanford University, Stanford, California, January 30 - February 1, 2012 SGP-TR-194.

Sonnenthal, E., A. Ito, N. Spycher, M. Yui, J. Apps, Y. Sugita, M. Conrad, and S. Kawakami, 2005. Approaches to modeling coupled thermal, hydrological, and chemical processes in the Drift Scale Heater Test at Yucca Mountain. International Journal of Rock Mechanics and Mining Sciences, 42:698-719.

Spycher N., Sonnenthal, E.L., Kennedy, B.M., 2011. Integrating multicomponent chemical geothermometry with parameter estimation computations for geothermal exploration. Geothermal Resource Council Transactions. 35:663-666.

Vosteen, H.-D., Schellschmidt, R., 2003. Influence of temperature on thermal conductivity, thermal capacity and thermal diffusivity for different types of rock. Physics and Chemistry of the Earth 28:499-509.

Xu, T., Spycher, N., Sonnenthal, E., Zhang, G., Zheng, L., \& Pruess, K., 2011. TOUGHREACT Version 2.0: A simulator for subsurface reactive transport under nonisothermal multiphase flow conditions. Computers and Geosciences, 37:763-774. 


\title{
Optimized multicomponent geothermometry applied to some geothermal area from the Great
} Basin, USA

\author{
L. Peiffer, N. Spycher, S. F. Simmons
}

\section{Introduction}

The selection of relevant minerals is critical for the multicomponent geothermometry, and the concentrations of minor elements like $\mathrm{Al}$ and $\mathrm{Mg}$ contents are known to be critical for the temperature estimation. Pang and Reed (1998) recognized this problem and proposed to constrain the multicomponent geothermometry approach by computing the Al activity assuming equilibrium of the fluid with a selected Al solid phase at all temperatures (i.e., their "Fix-Al" method). The "Fix-Al" method has shown to be quite useful, however its results can be quite sensitive to the choice of mineral selected to fix Al activity (see discussion in Peiffer et al, in prep).

Another approach proposed below to constrain $\mathrm{Al}$ and $\mathrm{Mg}$ concentrations is the numerical optimization of these elements concentrations by using GeoT (Spycher et al., 2011 and 2013) coupled with the parameter estimation software iTOUGH2 (Finsterle and Zhang, 2011). In this study, results were obtained by using the LevenbergMarquardt minimization algorithm of iTOUGH2 and directly minimizing 1) absolute values of the median of the saturation indices of all minerals for each water considered, 2) the spread of temperatures given by the equilibrium point $(\log (\mathrm{Q} / \mathrm{K})=0)$ of each mineral individually and 3), when processing multiple water analyses simultaneously, the standard deviation associated to the average of the different individual temperature estimates.

The optimized multicomponent geothermometry approach also allows estimating unknown parameters, such as the amount of waters diluting the deep geothermal fluid on its way to the surface ('cfact'), the percentage of gas lost during boiling (steam fraction 'sf'), as well as any dissolved elements concentration for which analyses are missing or erroneous (e.g., Al and Mg). An unlimited number of waters can be processed at the same time to reduce the degrees of freedom during optimization. Obviously, waters must have a common origin to provide realistic results.

The waters processed with GeoT-iTough2 were taken from the Interim Report on 'Assessment of Fluid-Mineral Equilibria' by Simmons (2012). The waters from Dixie Valley are not discussed here (these are the subject of a separate paper; Peiffer et al., in prep). For all the simulations, the thermodynamic database SOLTHERM.H06 (Reed and Palandri, 2006) was used. GeoT-iTough2 estimates were also compared to classical $\mathrm{SiO}_{2}, \mathrm{Na}-\mathrm{K}, \mathrm{Na}-\mathrm{K}-\mathrm{Ca}$ and $\mathrm{K} / \mathrm{Mg}$ geothermometers (Tables 1-5). Optimized parameters were the $\mathrm{Al}$ and $\mathrm{Mg}$ concentrations, and/or in some cases the steam fraction and dilution factor. When no gas analyses were available, the gas analysis of Dixie Valley well 76-7 DV96-8 (Simmons, 2012) was considered to reconstitute the geothermal water before phase separation (water+gas). This gas composition is assumed to be a typical geothermal gas composition. 
2. Selection of minerals and assumption

The selection of minerals was based on the following statement from the Interim Report by Simmons (2012): Mineralogical analyses (XRD analyses complete, thin section analyses in progress) of Beowawe, Dixie Valley, Mammoth, and Roosevelt confirm that quartz, feldspars (Na-feldspar, K-feldspar, plagioclase), illite (K-mica), chlorite, and calcite are common minerals in the reservoir rocks and that these are most likely to have the greatest influence on fluid-mineral equilibrium'.

Zeolites are relatively common minerals in geothermal systems and were also considered in this study. Pyrite, epidote and clays (smectite and illite), despite being also common in geothermal reservoir, were not taken into account in this work. Here is the reason why: pyrite and epidote contain $\mathrm{Fe}$ in their formula, and this element was not reported in the report. To overcome this issue, Fe could also be estimated by optimization, but estimation of several parameters at the same time $(\mathrm{Al}, \mathrm{Mg}+\mathrm{Fe})$ could lead to difficulties in optimization (e.g., wrong temperature estimates from local several minima in the object function). Smectite and illite are not considered either, making the assumption chlorite is the main mineral controlling Mg concentrations. Those three minerals have different temperature stability field, and therefore the optimization of $\mathrm{Mg}$ taking into account those three $\mathrm{Mg}$ minerals at the same time could also give erroneous or ambiguous. Furthermore, chlorite is believed to be a more common mineral in deep geothermal reservoir than smectite and illite. Therefore chlorite is the only $\mathrm{Mg}$ mineral considered during the optimization process. Microcline was used instead of illite, it will be shown later in this report that microcline saturation indices (SI) curve is in better agreement with other minerals SI curves.

In the following tables (1-5), GeoT-iTough2 results are shown for different runs, each considering a different suite and number of minerals: a) 4 minerals (quartz, microcline, albite, chlorite: clinochlore), b) 5 minerals (4 min + microcline), c) 6 minerals ( 5 min + zeolite: heulandite) and d) 7 minerals ( $6 \mathrm{~min}+$ calcite). Doing so allows an evaluation of the best suite of minerals for optimization process (best statistical indices), and therefore the best temperature estimation.

3. Results and discussion

\subsection{Desert Peak}

$\mathrm{Al}$ and $\mathrm{Mg}$ concentrations were optimized and steam fractions were taken from Simmons (2012). Best statistical indices (lowest RMED, RMSE, SDEV, MEAN; Figure 1) were obtained with 4 minerals, although '5 to 6 minerals' runs also provide good statistics. The GeoT temperature estimates $\left(4-6 \mathrm{~min}, 242^{\circ} \mathrm{C}-248^{\circ} \mathrm{C}\right)$ are higher than the classical geothermometers results $\left(205^{\circ} \mathrm{C}-235^{\circ} \mathrm{C}\right.$, except $\left.\mathrm{K}-\mathrm{Mg} 260^{\circ} \mathrm{C}\right)$. Lutz et al. (2009) identified zeolites and clays (illite-smectite) as minerals currently deposited in the geothermal reservoir at temperatures of $\sim 220^{\circ} \mathrm{C}$. In this study (Figure 1.C), the heulandite (zeolite) saturation indice curve shows a higher equilibrium temperature of $250^{\circ} \mathrm{C}$. 
As mentioned earlier, clays minerals such as illite and smectite cannot be considered together with chlorite because they all contain $\mathrm{Mg}$ and are characterized by different temperature stability fields. As an example, illite was considered in the optimization process (Figure 2), and its corresponding SI shows a large discrepancy compared to the other minerals inducing bad statistical indices on the temperature estimate. Instead, muscovite, also a K-mica, seems to be a better option: it shows an equilibrium temperature of $246^{\circ} \mathrm{C}$ similar to others minerals (Figure 1.B), and it doesn't contain any $\mathrm{Mg}$ in its formula. Microcline thermodynamic data are also considered more reliable than the ones for illite.

The saturation indices curve of calcite indicates a lower equilibrium temperature $\left(174^{\circ} \mathrm{C}\right)$ probably reflecting some degree of re-equilibration at lower temperatures (Figure 1.D).

Table 1. Maximum downhole measured temperatures, classical geothermometers estimates, GeoT results and optimized parameters values for Desert Peak waters. The quartz geothermometer equation is from Fournier and Potter (1982; conductive cooling formula). (F) and (G) respectively stands for the Na-K geothermometer from Fournier (1979) and Giggenbach (1988). Na-K-Ca geothermometer is from Fournier and Truesdell (1973) and KMg from Giggenbach (1988). The classical geothermometers were calculated taking into account the measured or optimized steam fractions. Optimized $\mathrm{Al}$ concentrations are in $\mathrm{mg} / \mathrm{l}$ and the optimized $\mathrm{Mg}$ in $\mu \mathrm{g} / \mathrm{l}$. Temperature in degrees Celsius. Max. Meas. T: maximum measured downhole temperature. sf: steam fraction. \#min and \#waters: respectively the numbers of minerals and water samples considered for the optimization.

\begin{tabular}{|c|c|c|c|c|c|c|c|c|c|c|c|c|c|c|}
\hline & \#min & \#waters & Samples & $\begin{array}{c}\text { Max. } \\
\text { Meas. T }\end{array}$ & $\mathrm{T}_{\text {quartz }}{ }^{*}$ & $\mathrm{~T}_{\mathrm{Na}-\mathrm{K}(\mathrm{F})}$ & $\mathrm{T}_{\mathrm{Na}-\mathrm{K}(\mathrm{G})}$ & $\mathrm{T}_{\mathrm{Na}-\mathrm{K}-\mathrm{Ca}}$ & $\mathrm{T}_{\mathrm{K}-\mathrm{Mg}}$ & $\mathrm{T}_{\mathrm{geoT}}$ & $\mathrm{T}_{\text {stdev }}$ & \multirow{18}{*}{ 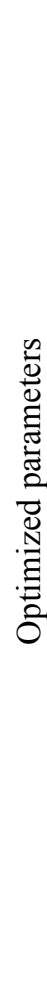 } & $\mathrm{Al}$ & $\mathrm{Mg}$ \\
\hline \multirow{17}{*}{$\frac{n}{0}$} & \multirow[t]{5}{*}{4} & \multirow[t]{5}{*}{5} & $21-1$ & 204 & 200 & 217 & 233 & 215 & 262 & 236 & 10 & & 0.27 & 6.7 \\
\hline & & & $67-21$ & 210 & 207 & 219 & 234 & 215 & 272 & 244 & 8 & & 0.28 & 11 \\
\hline & & & $77-21$ & 195 & 211 & 219 & 234 & 217 & 268 & 240 & 4 & & 0.18 & 4.2 \\
\hline & & & $86-21$ & 211 & 212 & 229 & 243 & 223 & 286 & 248 & 9 & & 0.25 & 5.3 \\
\hline & & & $74-21$ & 171 & 194 & 216 & 232 & 213 & 213 & 244 & 17 & & 0.42 & 1.4 \\
\hline & \multicolumn{3}{|c|}{ average } & 198 & 205 & 220 & 235 & 217 & 260 & 242 & 9 & & 0.28 & 5.6 \\
\hline & 5 & 5 & $21-1$ & & & & & & & 236 & 10 & & 0.29 & 7.3 \\
\hline & & & $67-21$ & & & & & & & 252 & 9 & & 0.27 & 6.3 \\
\hline & & & $77-21$ & & & & & & & 244 & 7 & & 0.27 & 2.7 \\
\hline & & & $86-21$ & & & & & & & 252 & 8 & & 0.26 & 1.2 \\
\hline & & & $74-21$ & & & & & & & 240 & 15 & & 0.42 & 1.8 \\
\hline & \multicolumn{3}{|c|}{ average } & & & & & & & 245 & 10 & & 0.30 & 3.9 \\
\hline & 6 & 5 & 21-1 & & & & & & & 244 & 12 & & 0.30 & 4.8 \\
\hline & & & $67-21$ & & & & & & & 252 & 10 & & 0.31 & 7.8 \\
\hline & & & $77-21$ & & & & & & & 248 & 6 & & 0.23 & 3.1 \\
\hline & & & $86-21$ & & & & & & & 260 & 12 & & 0.39 & 0.8 \\
\hline & & & $74-21$ & & & & & & & 240 & 15 & & 0.42 & 1.5 \\
\hline
\end{tabular}


Appendix D: DE-FOA-0000522

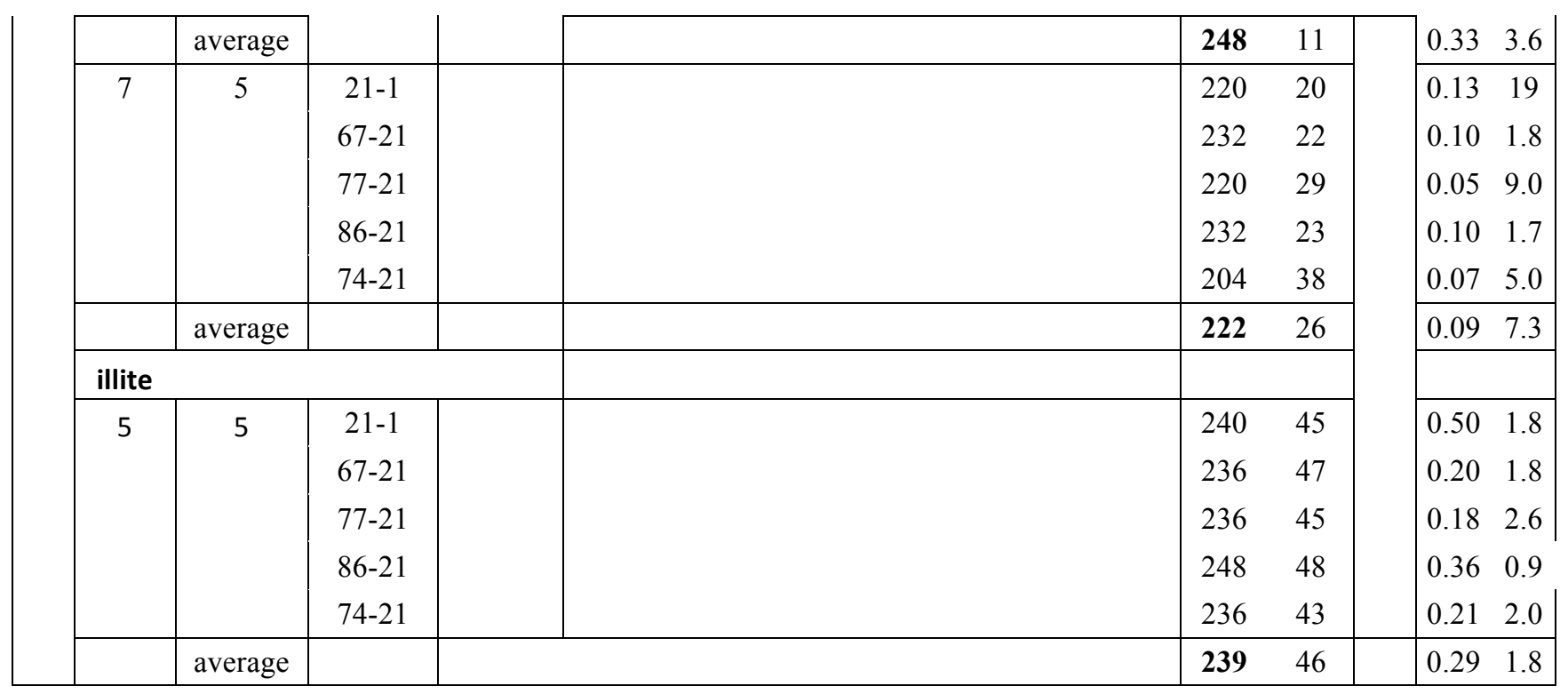



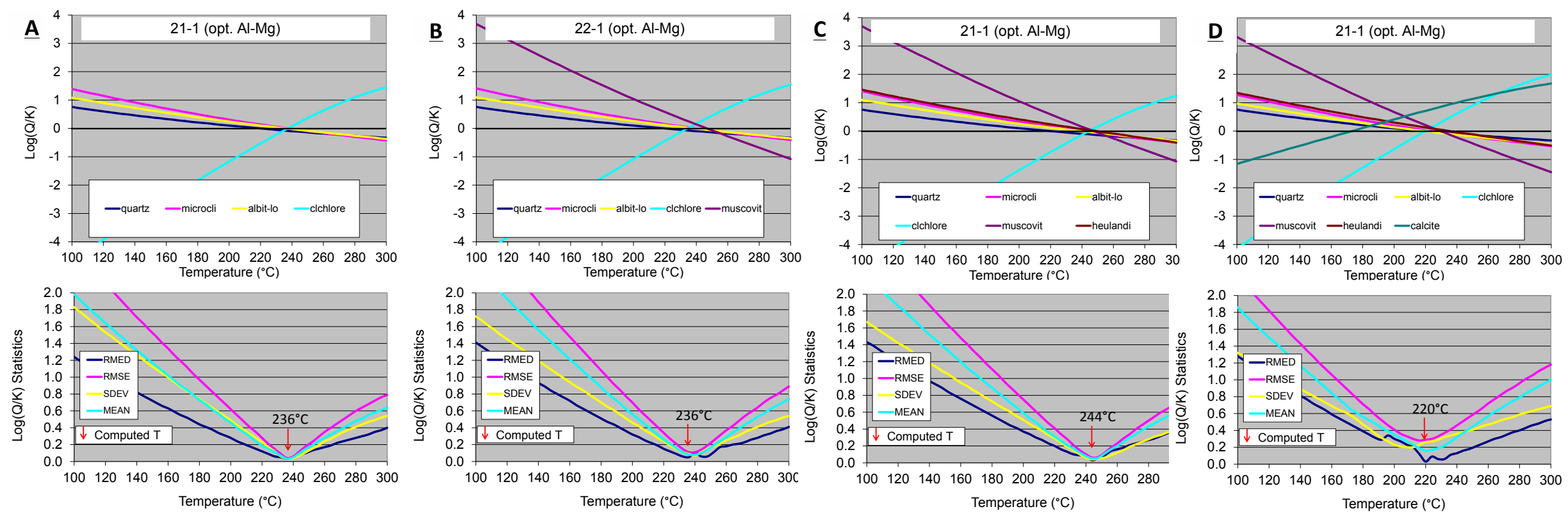

Figure 1. Mineral saturation indices $(\log (\mathrm{Q} / \mathrm{K}))$ computed with GeoT for well water well 21-1 from Desert Peak considering: A. 4 minerals, B. 5 minerals, C. 6 minerals, D. 7 minerals. Respective median (RMED), mean root squared (RMSE), standard deviation (SDEV) and average (MEAN) of $\log (\mathrm{Q} / \mathrm{K})$ values are also shown. The estimated temperatures are given by the lowest median of $(\log (\mathrm{Q} / \mathrm{K}))$ values. $\mathrm{Al}$ and $\mathrm{Mg}$ concentrations were estimated by optimization.
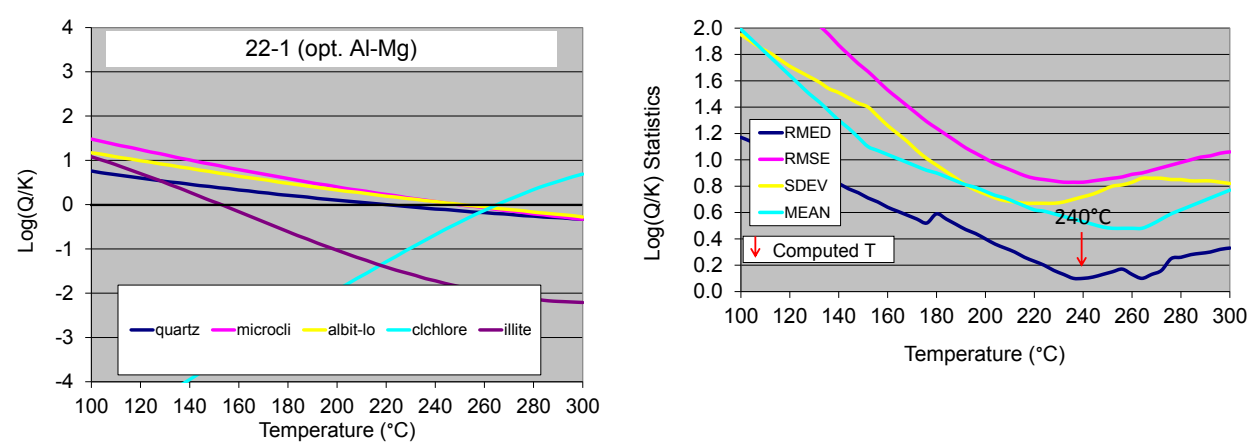

Figure 2. Similar to the 5-mineral run in Figure 1.B except that illite was used instead of muscovite. 


\subsection{Mammoth-Long Valley}

$\mathrm{Al}$ and $\mathrm{Mg}$ concentrations were optimized as well as steam fractions (unknown in Simmons, 2012). The ' 4 minerals' run show the best statistical indices although '5-6-7 minerals' runs statistics are also good (Figure 3). Computed temperatures are in between 204 and $214^{\circ} \mathrm{C}$, similar to the quartz and $\mathrm{Na}-\mathrm{K}-\mathrm{Ca}$ geothermometers $\left(196-210^{\circ} \mathrm{C}\right)$ but lower than the Na-K geothermometers $\left(225-240^{\circ} \mathrm{C}\right)$. K-Mg geothermometer gives a lower temperature estimate $\left(161^{\circ} \mathrm{C}\right)$. Maximum temperatures recorded for the well waters are between $174^{\circ} \mathrm{C}$ and $202^{\circ} \mathrm{C}$.

A steam fraction of 0.04 was obtained by optimization. Based on enthalpy calculation, this low steam fraction (if correct) would mean that the fluid was sampled at temperature slightly lower than the reservoir one, allowing only a small fraction of vapor to be lost: e.g. if the reservoir temperature is $214^{\circ} \mathrm{C}$, sampling temperature would be of $196^{\circ} \mathrm{C}$. Data on sampling temperatures would be necessary to check this hypothesis.

It should be mentioned that if some dilution occurs between the deep reservoir and the sampling point, GeoT temperature estimates are affected: e.g., considering an optimized concentration factor of 1.4 (to un-dilute the fluid) and the 4-mineral set, the computed GeoT temperature becomes $232{ }^{\circ} \mathrm{C}$ (Figure 4), and the statistical indices are still good.

Table 2. Maximum downhole measured temperatures, classical geothermometers estimates, GeoT results and optimized parameters values for Mammoth-Long Valley waters.

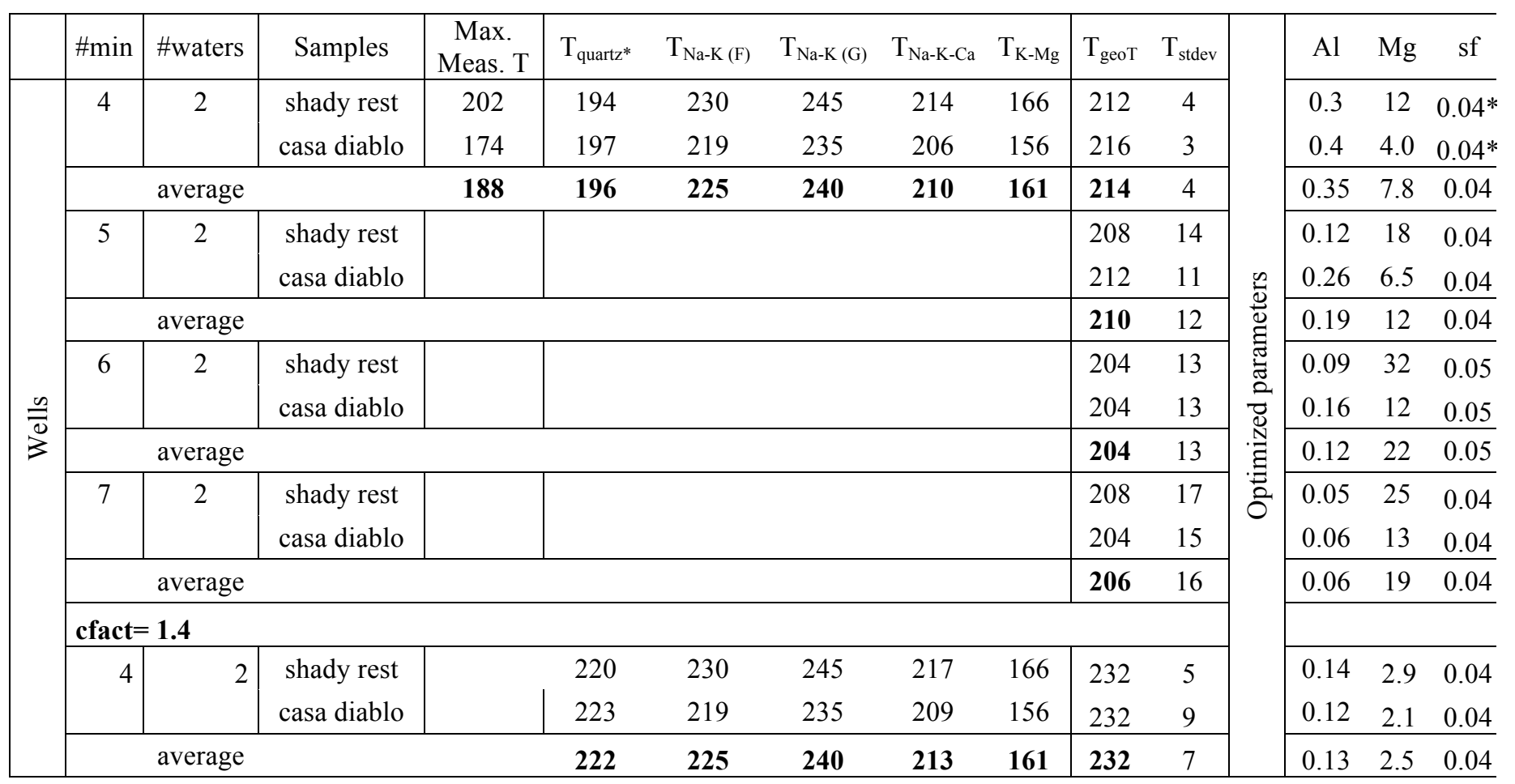



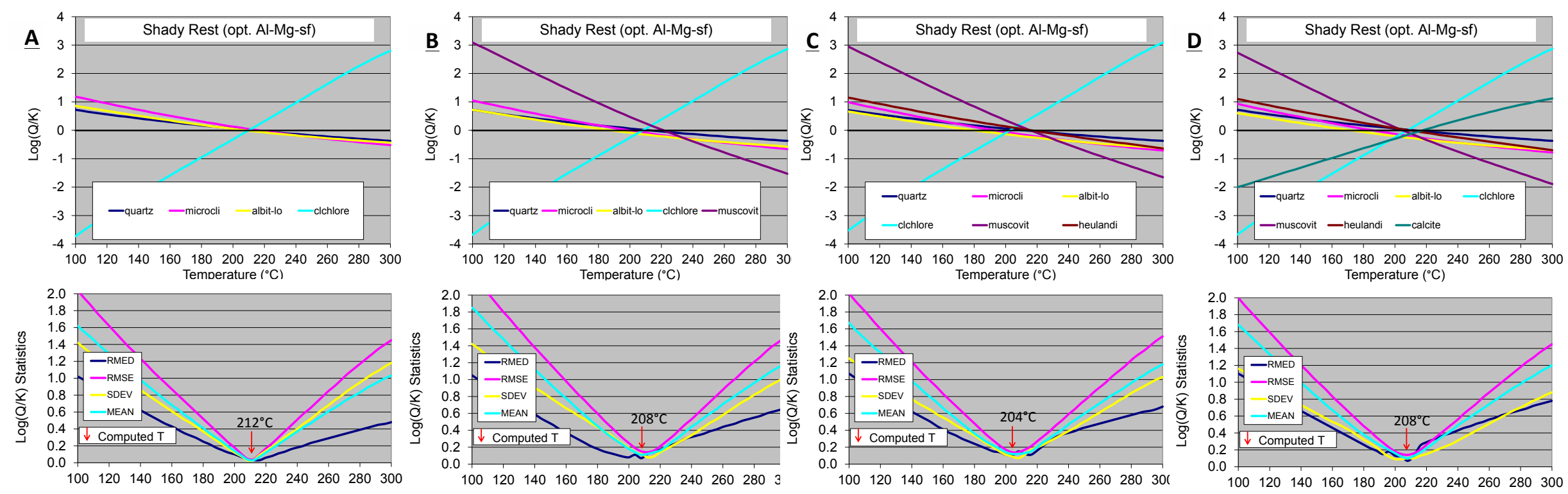

Temperature $\left({ }^{\circ} \mathrm{C}\right)$

100120140160180200220240260280

10012014016018020022024026028030 Temperature $\left({ }^{\circ} \mathrm{C}\right)$ Temperature ( $\left.{ }^{\circ} \mathrm{C}\right)$

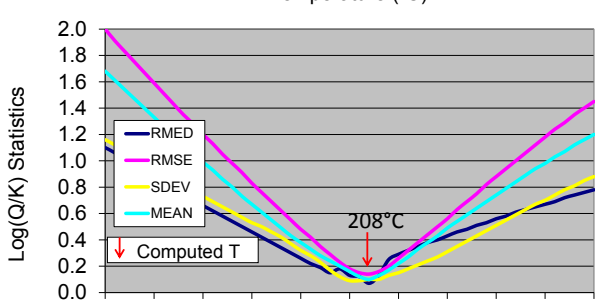

100120140160180200220240260280300

Figure 3. Mineral saturation indices $(\log (\mathrm{Q} / \mathrm{K}))$ computed with GeoT for water sampled in well 'Shady Rest' from Mammoth-Long Valley considering: A. 4 minerals, B. 5 minerals, C. 6 minerals, D. 7 minerals. Al-Mg concentrations and steam fraction were estimated by optimization.
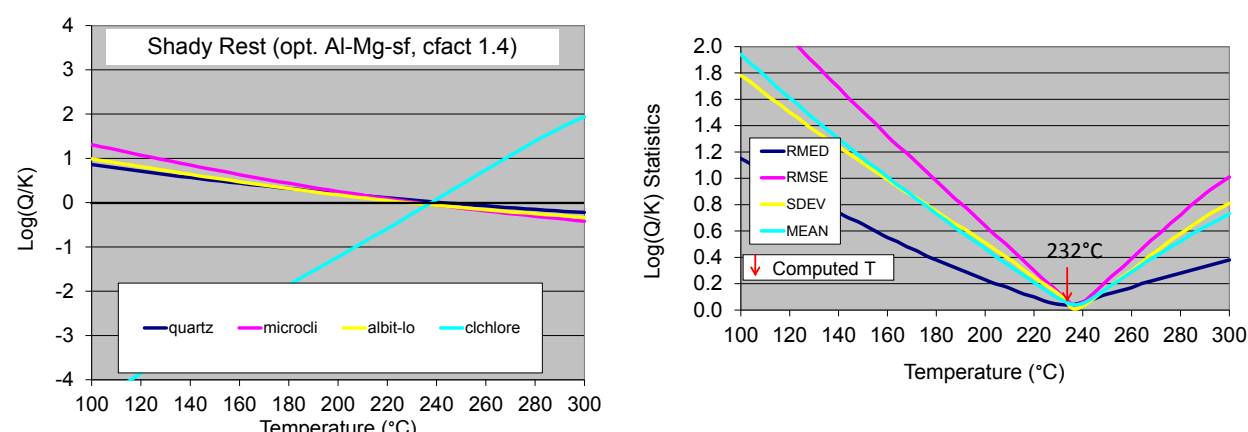

Figure 4. Similar to 4-mineral run from Figure 3.A except that a concentration factor of 1.4 was applied to the chemical composition of the fluid. Temperature $\left({ }^{\circ} \mathrm{C}\right)$ 
Appendix D: DE-FOA-0000522

\subsection{Roosevelt}

A steam fraction of 0.18 was considered as reported in Capuano and Cole (1982). Al and $\mathrm{Mg}$ were optimized.

All GeoT runs show relatively good clustering (Figure 5) and statistical indices (Table 3) and give similar temperature estimates $\left(296^{\circ} \mathrm{C}\right)$, higher than the classical geothermometers $\left(277-301^{\circ} \mathrm{C}\right)$. However, the GeoTestimated temperatures are $\sim 30^{\circ} \mathrm{C}$ higher than the bottom-hole temperature measurement in well $14-2\left(265^{\circ} \mathrm{C}\right)$.

Table 3. Maximum downhole measured temperatures, classical geothermometers estimates, GeoT results and optimized parameters values for Roosevelt sample.

\begin{tabular}{|c|c|c|c|c|c|c|c|c|c|c|c|c|c|c|c|c|}
\hline \multirow{5}{*}{$\frac{\infty}{\overline{0}}$} & $\# \min$ & \#waters & Samples & sf & $\begin{array}{c}\text { Max. } \\
\text { Meas. T }\end{array}$ & $\mathrm{T}_{\text {quartz* }}$ & $\mathrm{T}_{\mathrm{Na}-\mathrm{K}(\mathrm{F})}$ & $\mathrm{T}_{\mathrm{Na}-\mathrm{K}(\mathrm{G})}$ & $\mathrm{T}_{\text {Na-K-Ca }}$ & $\mathrm{T}_{\mathrm{K}-\mathrm{Mg}}$ & $\mathrm{T}_{\text {geoT }}$ & $\mathrm{T}_{\text {stdev }}$ & \multirow{5}{*}{ 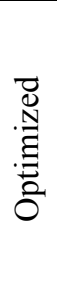 } & \multirow{5}{*}{ 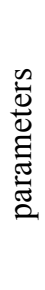 } & $\mathrm{Al}^{*}$ & $\mathrm{Mg}^{*}$ \\
\hline & 4 & 1 & & 0.18 & 265 & 282 & 277 & 287 & 290 & 301 & 296 & 2 & & & 0.24 & 1.5 \\
\hline & 5 & 1 & & 0.18 & & & & & & & 296 & 11 & & & & \\
\hline & 6 & 1 & & 0.18 & & & & & & & 296 & 13 & & & & \\
\hline & 7 & 1 & & 0.18 & & & & & & & 296 & 12 & & & & \\
\hline
\end{tabular}



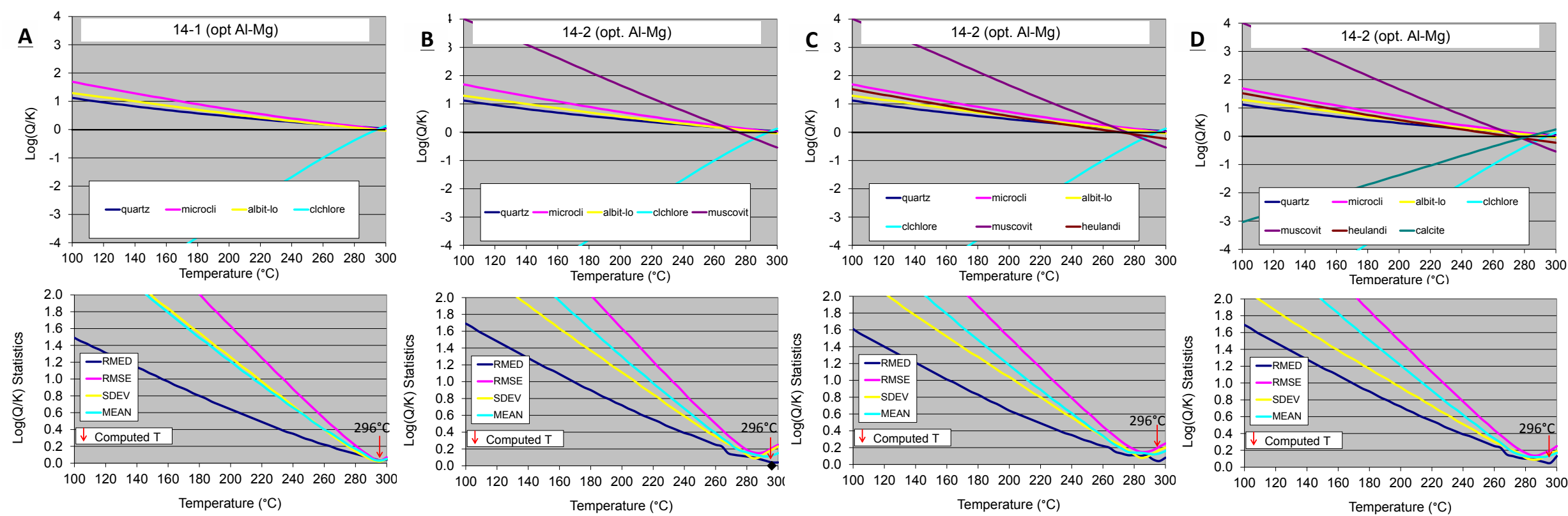

Figure 5. Mineral saturation indices $(\log (\mathrm{Q} / \mathrm{K}))$ computed with GeoT for water sampled in well '14-2' from Roosevelt considering: A. 4 minerals, B. 5 minerals, C. 6 minerals, D. 7 minerals. Al-Mg concentrations were estimated by optimization. 


\subsection{Raft River}

$\mathrm{Al}$ and $\mathrm{Mg}$ concentrations as wells as steam fractions were optimized. The ' 4 minerals' run shows the best statistical indices, although the 6- and 7- mineral runs also appear good (Figure 6). GeoT estimates are similar to the quartz geothermometer results, and slightly above the maximum measured temperatures registered in wells $\left(140-148^{\circ} \mathrm{C}\right.$, Ayling et al. 2011). Other geothermometers gives higher temperatures (188-231 $\left.{ }^{\circ} \mathrm{C}\right)$. Nevertheless, this discrepancy in temperatures could reflect mixing with superficial water, e.g. if the well waters are diluted by a factor of 2.5 with some dilute superficial groundwaters, the computed temperature considering the 4 minerals list would be $232^{\circ} \mathrm{C}$ (Figure 7), like the Na-K (G) temperature estimate. Ayling et al. (2011) also mention: 'We concur with earlier studies that attributed the high dissolved salt concentrations at intermediate depths in the field to evaporitic sediments in the Tertiary basin fill at Raft River (Molling, 2006)'. However, they don't mention which type of evaporitic salts. If the deep geothermal fluid leaches evaporitic salts (halite, sylvite?) on its way to the surface, then the $\mathrm{Na}-\mathrm{K}$ geothermometer estimates has to be considered carefully.

Optimized steam fractions are low $(<0.01 \%)$ suggesting that the geothermal fluid hasn't boiled significantly. $\delta^{18} \mathrm{O}$ and $\delta \mathrm{D}$ values of Raft River geothermal wells (Ayling et al. 2011) support this hypothesis, the waters don't show the typical shift due to boiling or evaporation.

Table 4. Maximum downhole measured temperatures, classical geothermometers estimates, GeoT results and optimized parameters values for Raft River samples.

\begin{tabular}{|c|c|c|c|c|c|c|c|c|c|c|c|c|c|c|c|}
\hline & $\# \min$ & \#waters & Samples & $\begin{array}{c}\text { Max. } \\
\text { Meas. T }\end{array}$ & $\mathrm{T}_{\text {quartz* }}$ & $\begin{array}{c}\mathrm{T}_{\mathrm{Na}-\mathrm{K}} \\
\text { (F) }\end{array}$ & $\begin{array}{l}\mathrm{T}_{\mathrm{Na}-\mathrm{K}} \\
\text { (G) }\end{array}$ & $\mathrm{T}_{\mathrm{Na}-\mathrm{K}-\mathrm{Ca}}$ & $\mathrm{T}_{\mathrm{K}-\mathrm{Mg}}$ & $\mathrm{T}_{\mathrm{geoT}}$ & $\mathrm{T}_{\text {stdev }}$ & \multirow{17}{*}{ 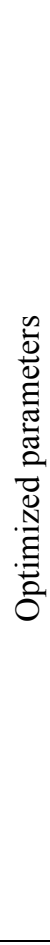 } & $\mathrm{Al}$ & $\mathrm{Mg}$ & sf \\
\hline \multirow{16}{*}{$\frac{n}{\overline{0}}$} & \multirow[t]{3}{*}{4} & \multirow[t]{3}{*}{3} & RRG-1 & 137 & 154 & 236 & 250 & 209 & 206 & 160 & 9 & & 0.05 & 7.1 & 0.0012 \\
\hline & & & RRG-4 & 134 & 155 & 200 & 216 & 181 & 172 & 160 & 5 & & 0.09 & 2.6 & 0.0012 \\
\hline & & & RRG-7 & 119 & 160 & 215 & 231 & 199 & 188 & 164 & 6 & & 0.03 & 23 & 0.017 \\
\hline & \multicolumn{3}{|c|}{ average } & 130 & 156 & 217 & 232 & 196 & 189 & 161 & 6 & & 0.06 & 11 & 0.0065 \\
\hline & \multirow[t]{3}{*}{5} & \multirow[t]{3}{*}{3} & RRG-1 & & & & & & & 176 & 13 & & 0.07 & 9.2 & 0.001 \\
\hline & & & RRG-4 & & & & & & & 168 & 8 & & 0.08 & 1.9 & 0.001 \\
\hline & & & RRG-7 & & & & & & & 176 & 8 & & 0.04 & 14 & 0.0014 \\
\hline & \multicolumn{3}{|c|}{ average } & & & & & & & 173 & 10 & & 0.06 & 8.5 & 0.0011 \\
\hline & \multirow[t]{4}{*}{6} & \multirow[t]{3}{*}{3} & RRG-1 & & & & & & & 160 & 16 & & 0.03 & 5.5 & 0.001 \\
\hline & & & RRG-4 & & & & & & & 148 & 19 & & 0.02 & 0.6 & 0.0016 \\
\hline & & & RRG-7 & & & & & & & 160 & 15 & & 0.02 & 6.1 & 0.001 \\
\hline & & average & & & & & & & & 156 & 16 & & 0.02 & 4.1 & 0.0012 \\
\hline & \multirow[t]{4}{*}{7} & \multirow[t]{3}{*}{3} & RRG-1 & & & & & & & 164 & 14 & & 0.03 & 15 & 0.0035 \\
\hline & & & RRG-4 & & & & & & & 160 & 16 & & 0.08 & 2.6 & 0.001 \\
\hline & & & RRG-7 & & & & & & & 164 & 13 & & 0.01 & 72 & 0.0055 \\
\hline & & average & & & & & & & & 163 & 14 & & 0.04 & 30 & 0.0033 \\
\hline
\end{tabular}


Appendix D: DE-FOA-0000522

\begin{tabular}{|c|c|c|c|c|c|c|c|c|c|c|c|c|}
\hline \multicolumn{13}{|c|}{ cfact $=1.4$} \\
\hline \multirow[t]{3}{*}{4} & 3 & RRG-1 & 218 & 236 & 250 & 219 & 206 & 232 & 7 & 0.03 & 1.3 & 0.0108 \\
\hline & & RRG-4 & 218 & 200 & 216 & 190 & 172 & 232 & 5 & 0.05 & 0.7 & 0.0182 \\
\hline & & RRG-7 & 224 & 215 & 231 & 208 & 188 & 236 & 8 & 0.02 & 10 & 0.0286 \\
\hline \multicolumn{3}{|c|}{ average } & 220 & 217 & 232 & 206 & 189 & 233 & 7 & 0.04 & 4 & 0.0192 \\
\hline
\end{tabular}



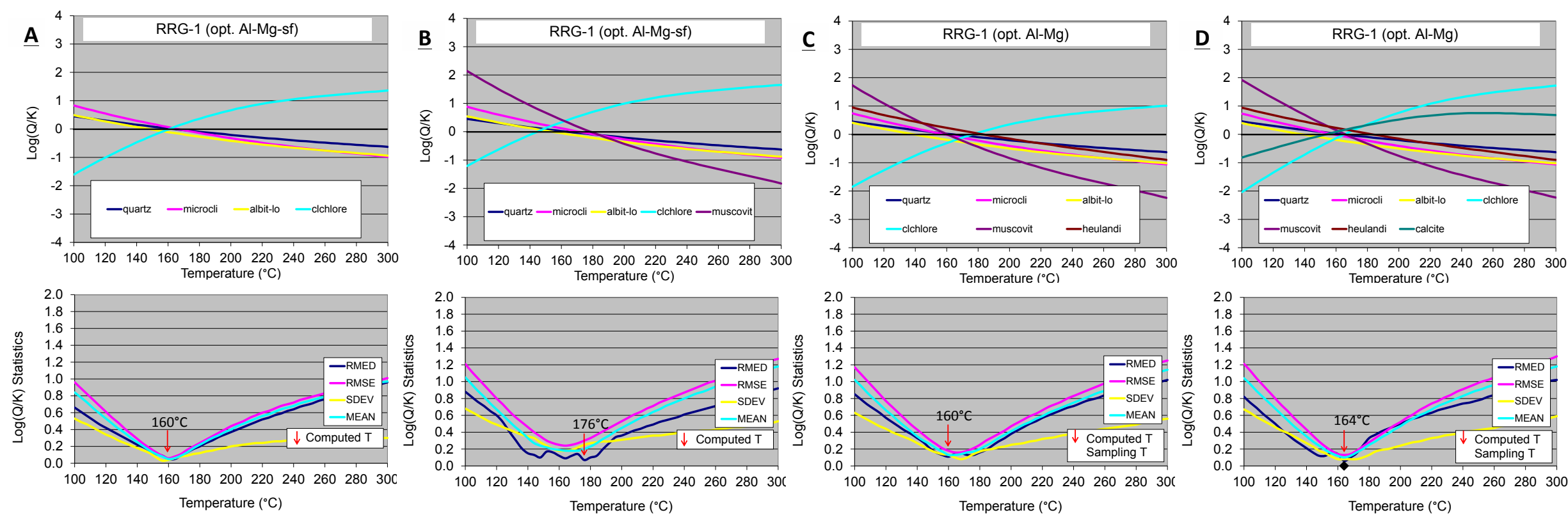

Figure 6. Mineral saturation indices $(\log (\mathrm{Q} / \mathrm{K}))$ computed with GeoT for water sampled in well 'RRG-1' from Raft River considering: A. 4 minerals, B. 5 minerals, C. 6 minerals, D. 7 minerals. Al-Mg concentrations and steam fraction were estimated by optimization.
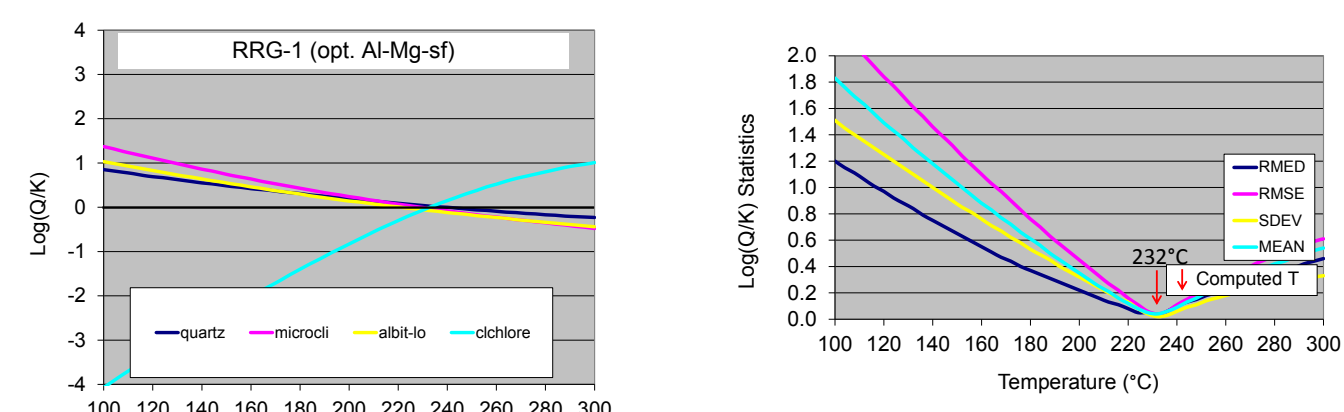

Figure 7. Similar to the 4-mineral run in Figure 6.A except that a concentration factor of 1.4 was applied. 


\subsection{Beowawe}

The charge balances of the reported analyses are high (+17-38\%). For allowing convergence of GeoT, the $\mathrm{HCO}_{3}$ content was adjusted to allow a good charge balance $(<1 \%) . \mathrm{HCO}_{3}$ content was therefore set to: $415 \mathrm{mg} / \mathrm{l}$ for well Rossi 21-19, $425 \mathrm{mg} / 1$ for well Ginn 1-13 and $627 \mathrm{mg} / 1$ for well 85-18.

The Al-Mg concentrations and the steam fraction were optimized. Best statistical indices are obtained with 4 to 6 minerals (Figure 8). The GeoT estimates $\left(248^{\circ} \mathrm{C}-249^{\circ} \mathrm{C}\right)$ is similar to $\mathrm{Na}-\mathrm{K}(\mathrm{G})$ estimates $\left(235^{\circ} \mathrm{C}-250^{\circ} \mathrm{C}\right)$, but higher than other classical geothermometer results as well as maximum temperatures measured in those wells (160$211^{\circ} \mathrm{C}$ ). The lack of clustering with the calcite curve may be related to the uncertain $\mathrm{HCO}_{3}$ concentrations estimated by charge balance. New water analyzes would be required to check these results.

Table 5. Maximum downhole measured temperatures, classical geothermometers estimates, GeoT results and optimized parameters values for Beowawe samples.

\begin{tabular}{|c|c|c|c|c|c|c|c|c|c|c|c|c|c|c|c|}
\hline & $\# \min$ & \#waters & Samples & $\begin{array}{c}\text { Max. } \\
\text { Meas. T }\end{array}$ & $\mathrm{T}_{\text {quartz* }}$ & $\mathrm{T}_{\mathrm{Na}-\mathrm{K}(\mathrm{F})}$ & $\mathrm{T}_{\mathrm{Na}-\mathrm{K}(\mathrm{G})}$ & $\mathrm{T}_{\mathrm{Na}-\mathrm{K}-\mathrm{Ca}}$ & $\mathrm{T}_{\mathrm{K}-\mathrm{Mg}}$ & $\mathrm{T}_{\mathrm{geoT}}$ & $\mathrm{T}_{\text {stdev }}$ & \multirow{17}{*}{ 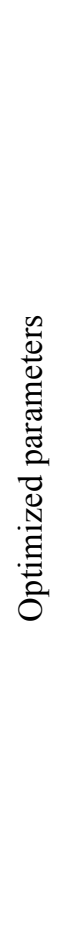 } & $\mathrm{A} 1^{*}$ & $M g *$ & $\mathrm{sf}^{*}$ \\
\hline \multirow{16}{*}{$\stackrel{0}{\overline{0}}$} & \multirow[t]{3}{*}{4} & \multirow[t]{3}{*}{3} & Rossi & 198 & 227 & 215 & 231 & 173 & 78 & 248 & 2 & & 1.08 & 0.24 & 0.15 \\
\hline & & & Ginn & 211 & 209 & 253 & 266 & 211 & 146 & 244 & 8 & & 1.08 & 0.24 & 0.13 \\
\hline & & & $85-18$ & 160 & 231 & 238 & 252 & 223 & 151 & 256 & 11 & & 0.81 & 0.19 & 0.13 \\
\hline & \multicolumn{3}{|c|}{ average } & 190 & 222 & 235 & 250 & 202 & 125 & 249 & 7 & & 0.99 & 0.23 & 0.14 \\
\hline & 5 & 3 & Rossi & & & & & & & 248 & 7 & & & & \\
\hline & & & Ginn & & & & & & & 244 & 10 & & same & as witl & $4 \min$ \\
\hline & & & $85-18$ & & & & & & & 256 & 10 & & & & \\
\hline & \multicolumn{3}{|c|}{ average } & & & & & & & 249 & 9 & & & & \\
\hline & \multirow[t]{4}{*}{6} & \multirow[t]{3}{*}{3} & Rossi & & & & & & & 244 & 17 & & \multirow{3}{*}{\multicolumn{3}{|c|}{ same as with $4 \mathrm{~min}$}} \\
\hline & & & Ginn & & & & & & & 244 & 13 & & & & \\
\hline & & & $85-18$ & & & & & & & 256 & 9 & & & & \\
\hline & & average & & & & & & & & 248 & 13 & & & & \\
\hline & \multirow[t]{4}{*}{7} & \multirow[t]{3}{*}{3} & Rossi & & & & & & & 244 & 49 & & \multirow{3}{*}{\multicolumn{3}{|c|}{ same as with 4 min }} \\
\hline & & & Ginn & & & & & & & 244 & 40 & & & & \\
\hline & & & $85-18$ & & & & & & & 256 & 35 & & & & \\
\hline & & average & & & & & & & & 248 & 41 & & & & \\
\hline
\end{tabular}



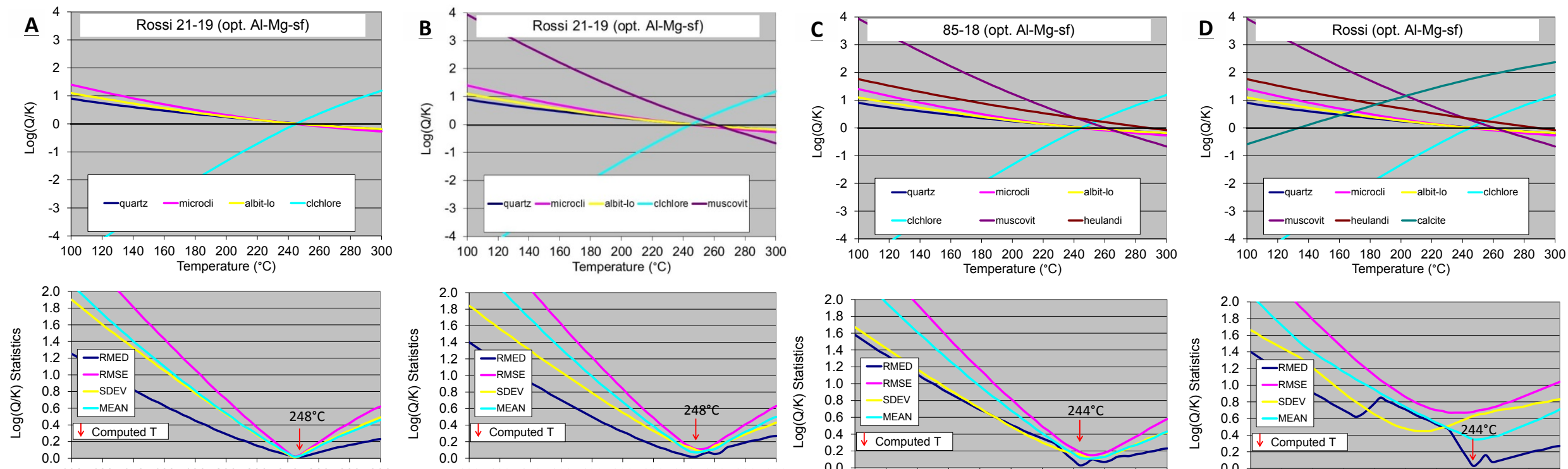

$100 \quad 120140 \quad 160 \quad 180200 \quad 220 \quad 240 \quad 260 \quad 280 \quad 300$ Temperature $\left({ }^{\circ} \mathrm{C}\right)$
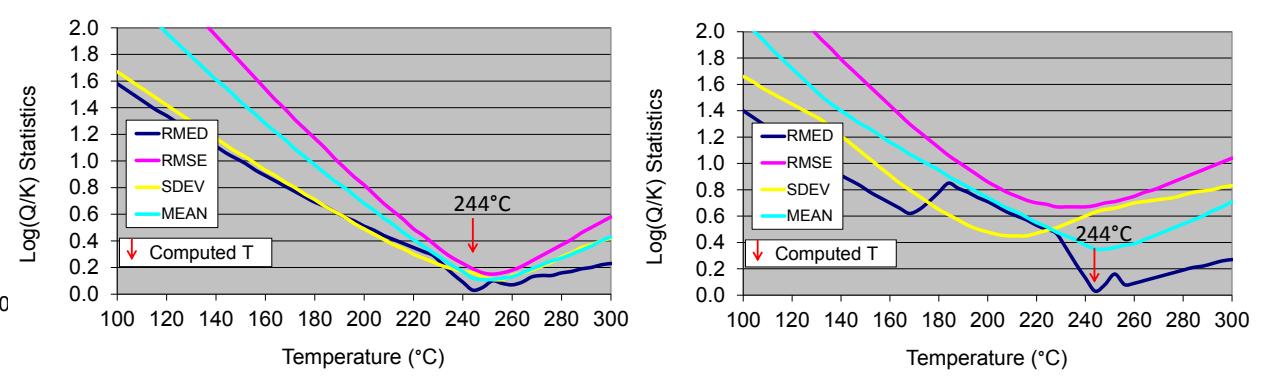

Figure 8. Mineral saturation indices $(\log (\mathrm{Q} / \mathrm{K}))$ computed with GeoT for water sampled in well 'RRG-1' from Beowawe considering: A. 4 minerals, B. 5 minerals, C. 6 minerals, D. 7 minerals. Al-Mg concentrations and steam fraction were estimated by optimization. 
4. Summary and further considerations

- In all cases, computed temperatures are higher than maximum well bottom-hole temperature. This observation could reflect two things: the wells are fed by a higher temperature fluid coming from greater depth, and/or bottom-hole temperature measurements are not correct. It has been mentioned in several studies (e.g. Chapman et al., 1984) that bottom-hole temperatures are generally lower than the true static formation temperature due to circulation of drilling fluid. It would be interesting to know how the temperature was measured, if for example it was measured during the drilling. In this case, the measured temperatures could be underestimated.

- $\quad$ Except from Mammoth-Long Valley and Roosevelt waters, classical geothermometer estimates give a wide temperature range different from the GeoT-iTough2 estimates. Introducing a concentration factor with GeoT allows making match the GeoT estimates with the $\mathrm{Na}-\mathrm{K}$ geothermometer results.

- $\quad$ The mineral list seems satisfactory since the different minerals are usually giving similar equilibrium temperature, except for calcite at Desert Peak and Beowawe.

- $\quad$ Optimized $\mathrm{Al}$ and $\mathrm{Mg}$ concentrations are in the same range as the concentrations expected in a typical deep hot geothermal reservoir (see discussion about Dixie Valley in Peiffer et al., in prep).

- Sampling temperature data are needed to check if the optimized steam fractions are reasonable.

- $\quad$ The $\mathrm{Na} / \mathrm{Cl}$ ratio of the Desert Peak, Raft River and Roosevelt waters is close to 1 . Does this observation reflect the mixing with evaporitic $\mathrm{NaCl}$ waters and/or halite dissolution after re-equilibration? At Desert Peak and Raft River, the discrepancy between $\mathrm{Na}-\mathrm{K}$ geothermometer and GeoT results could be explained by some evaporitic salt leaching?

\section{References}

Ayling, B., Molling, P., Nye, R., Moore, J., 2011. Fluid geochemistry at the Raft River Geothermal field, Idaho: New data and hydrogeological implications. Proceedings of the Thirty-Sixth Workshop on Geothermal Reservoir Engineering Stanford University, Stanford, California, January 31 - February 2, SGP-TR-191.

Chapman, D.S., Keho, T.H., Bauer, M.S., Picard, M.D., 1984. Heat flow in the Uinta basin determined from bottom hole temperature (BHT) data. Geophysics 49, 453-466. 
Finsterle, S., Zhang, Y., 2011. Solving iTOUGH2 simulation and optimization problems using the PEST protocol, Environ. Model.Softw. 26, 959-968Reed and Palandri, 2006

Fournier, R.O., 1979. A Revised Equation for the Na/K Geothermometer.” Geoth. Resources Council Transactions $3,221-224$.

Fournier, R.O., Potter, R.W., 1982. A revised and expanded silica (quartz) geothermometer. Geotherm. Resourc. Counc. Bull. 11, 3-12.

Giggenbach, W.F., 1988. Geothermal solute equilibria: Derivation of Na-K-Mg-Ca geoindicators. Geochim. Cosmochim. Acta 52, 2 749-2 765.

Molling, P., 2006. Integration of geochemistry into the preliminary conceptual model of the Raft River geothermal system. Confidential report prepared by G7geochem, Santa Rosa, CA. 17pp.

Pang, Z.H., Reed, M.H., 1998. Theoretical chemical thermometry on geothermal waters: problems and methods. Geochim. Cosmochim. Acta 62, 1083-1091.

Peiffer, L., Spycher, N., Kennedy, M, Iovenitti, J. Optimized multicomponent vs. classical geothermometry: insights from modeling studies at the Dixie Valley geothermal area. Geothermics (in prep.).

Simmons, S.F., 2012. Advances in Hydrogeochemical Indicators for the Discovery of New Geothermal Resources in the Great Basin, USA. Interim Report on Assessment of Fluid-Mineral Equilibria. Unpublished report.

Spycher et al., 2013. Multicomponent Solute Geothermometry Revisited (in prep.)

Spycher N., Sonnenthal E., and Kennedy B.M. (2011) Integrating Multicomponent Chemical Geothermometry with Parameter Estimation Computations for Geothermal Exploration. Geothermal Resources Council Transactions, 35 , 663-666. 


\section{MULTICOMPONENT GEOTHERMOMETRY SUMMARY RESULTS USING DIXIE} VALLEY WATERS

L. Peiffer, C. Wanner, N. Spycher, E.L. Sonnenthal, N.F. Spycher, and B.M. Kennedy

\section{Assumption}

The multicomponent geothermometry GeoT code coupled with numerical optimization was applied to different groups of Dixie Valley waters, as identified as part of another GTP project (Spycher et al., geothermometry AOP). The parameters estimated by optimization were the Al and $\mathrm{Mg}$ concentrations; the dilution/concentration factor ('cfact', representing concentration when its value is less than 1); and also the steam fraction ('sf', the fraction of gas in the total discharge) when not reported by Goff et al. (2002). For waters without gas analyses (e.g., springs), the following average gas composition was estimated from analyses of gas samples from geothermal wells (Goff et al., 2002) to reconstitute the 'pre-boiled' fluid composition: 99.8

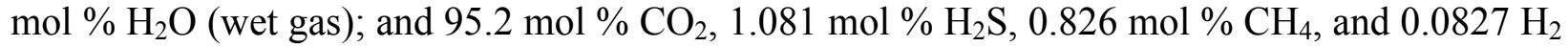
(dry gas). The chemical compositions of the selected waters subjected to geothermometry calculations, as well as sampling temperatures, are shown in Table 1. Corresponding multicomponent (GeoT-iTOUGH2 estimates) and classical geothermometry results, together with parameters estimated by optimization, are listed in Table 2 . When several waters could be identified as belonging to a same group, GeoT-iTOUGH2 was run using the analyses of these waters simultaneously to better constrain the optimization process. The average computed temperatures for these groups of waters are also reported in Table 2 and discussed below.

For numerical optimization using multiple waters (of the same group), the best results were obtained by limiting the number of minerals to the set of four key minerals present in the lopolith reservoir: quartz, albite, microcline, and chlorite. These minerals are also present in all the other geological layers of Dixie Valley, with the exception of chlorite, which is usually not present in the alluvial-colluvial deposits (Lutz, XRD unpublished data). Simultaneous optimization of multiple waters including a larger number of minerals proved to be difficult because it significantly increased the number of local (false) minima of the objective function. For this reason, further investigations are being conducted to evaluate efficient alternative minimization procedures that could be used successfully with a large number of minerals when multiple waters are processed simultaneously.

\section{Production wells}

Production wells from Section 7 were first considered. Numerical optimization of $\mathrm{Al}$ and $\mathrm{Mg}$ concentrations and the dilution/concentration factor were performed using analyses of water and gas samples from 6 wells from Section 7 (\#1, Table 2). Measured steam fractions (0.15-0.18) were available and input into GeoT to reconstruct the deep fluid composition. Doing so resulted in an estimated average temperature of $250^{\circ} \mathrm{C}$, close to the range of measured downhole temperatures in Section 7 wells $\left(240-250^{\circ} \mathrm{C}\right)$. The dilution/concentration factor was optimized to take into account the reservoir salinity increase caused by reinjection. The optimized value suggests an increase in reservoir salinity of $\sim 15-25 \%$ after production, consistent with observations by Kennedy et al. (1999). In general, the Al concentrations estimated by 
optimization (Table 2) are fairly consistent with the reactive transport model results presented earlier $(0.32 \mathrm{mg} / \mathrm{l}$, simulation $1, \# 1)$, and within the range of measured "dissolved" $(<0.2 \mu \mathrm{m}$ filtered) and "total" $(0.45 \mu \mathrm{m}$ filtered) Al concentrations (Table 1). However, the optimized $\mathrm{Mg}$ concentrations are much lower than field analyses (Table 2) but significantly higher than previously modeled values $(\sim 0.07 \mu \mathrm{g} / \mathrm{l})$. It should be noted that because $\mathrm{Mg}$ concentrations are constrained only by one $\mathrm{Mg}$ mineral in this case (chlorite), these results are strongly dependent on the thermodynamic data used for this mineral.

Waters from three Section 33 wells were processed in a similar manner. The average GeoT estimated temperature $\left(247^{\circ} \mathrm{C}\right)$ and values of optimized parameters (Table 2, \#2) are similar to results obtained with data from the Section 7 wells (Table 2, \#1).

The classical quartz and Na-K geothermometers estimates for both Section 33 and 7 wells (average respectively of $250-257^{\circ} \mathrm{C}$ and $253-260^{\circ} \mathrm{C}$ ) are in reasonably good agreement with GeoT results. However, the $\mathrm{Na}-\mathrm{K}-\mathrm{Ca}$ and $\mathrm{K}-\mathrm{Mg}$ geothermometers give somewhat lower temperatures for both sections $\left(231-236^{\circ} \mathrm{C}\right)$. Reinjected fluids are a mixture of separated brines and superficial waters with higher content in $\mathrm{Ca}$ and $\mathrm{Mg}$, possibly causing the last two geothermometers to yield lower temperatures.

\section{Pre-production wells}

Pre-production wells from sections 33 and 7 also show similar GeoT estimated temperatures $\left(256{ }^{\circ} \mathrm{C}\right.$ and $\left.247^{\circ} \mathrm{C}\right)$. The classical geothermometer estimates in this case are mostly within the standard deviation associated with the GeoT estimates $\left(247-261^{\circ} \mathrm{C}\right)$, except for the $\mathrm{K} / \mathrm{Mg}$ geothermometer (\#3 and \#4, Table 2).

Waters from Section 18 pre-production wells were also examined, considering the only two available analyses reported by Goff et al. (2002) for Section 18 wells (Table 2, \#5). The steam fraction (of the total steam+water discharge) was not reported for these wells, therefore this parameter was estimated by optimization together with $\mathrm{Al}$ and $\mathrm{Mg}$ concentrations. No dilution or concentration was considered ('cfact' set to 1) because pre-production well waters should represent the original reservoir brine. The reservoir temperature estimated by GeoT in this case $\left(246^{\circ} \mathrm{C}\right)$ is similar to that estimated for other sections 7 and 33 production wells. The optimized steam fraction for these wells is within the range of steam fraction values observed for other Dixie Valley wells (Table 1). Similarly, the optimized Al and $\mathrm{Mg}$ concentrations are in line with optimized values for production wells (Table 2). However, the quartz, Na-K and Na-K-Ca geothermometers give somewhat lower temperatures (Table 2) that are more in line with measured downhole temperatures for Section 18 wells reported by Waibel (1987) $\left(225^{\circ} \mathrm{C}\right)$.

The divergence between the classical geothermometers, measured downhole temperatures and GeoT estimates for the Section 18 wells could reflect the following process. GeoT-estimated temperatures may represent the equilibrium temperature of fluids originating from hotter conditions at greater depths. The bottom of well 32-18 is located in the basaltic rocks (Tmb), and the water in this well could be mixed with a hotter fluid coming from the underlying lopolith reservoir. Examining the water isotopic composition of the pre-production wells, there is almost no variation in pre-flash $\delta \mathrm{D}$ values $(-131$ to $-129 \%)$ and only a small range in $\delta^{18} \mathrm{O}(-14.44$ to 
14.07\%) between pre-production wells from sections 33, 7 and 8 (Kennedy et al. 1999), attesting that those fluids could have a common origin.

\section{Other geothermal and on-site wells ('ogo') wells 45-14 and 62-21}

Because of their difference in chemical compositions compared to production wells, the water analyses from the 'ogo' wells were processed separately. The GeoT estimate for well 45-14 $\left(224^{\circ} \mathrm{C}\right)$ is higher than classical geothermometer estimates by up to $\sim 30^{\circ} \mathrm{C}$, the latter being more in line with measured maximum downhole temperatures about $196^{\circ} \mathrm{C}$ (Table 2, \#6). Steam fractions were not reported for this well. The steam fraction estimated by optimization (0.08) is lower than at other production wells, but similar to steam fractions reported for other nonproductive wells (e.g., well 27-32: 0.05; Goff et al., 2002). The optimized Al concentration (0.43 $\mathrm{mg} / \mathrm{l})$ is similar to measured "total" ( $0.45 \mu \mathrm{m}$ filtered) concentrations $(\sim 0.23 \mathrm{mg} / \mathrm{l})$. However, the $\mathrm{Mg}$ concentration is an order of magnitude higher $(6.21 \mu \mathrm{g} / \mathrm{l})$ than concentrations optimized previously for other wells (Table 2). The data from well 45-15 show discrepancies between GeoT results, classical geothermometer estimates, and measured temperature that are similar in nature to the case of Section 18 pre-production wells. As for Section 18 wells, this could reflect higher temperature fluids at depths below the well bottom.

For well 62-21, GeoT yields a temperature estimate of $176^{\circ} \mathrm{C}$ (Table 2, \#7). The steam fraction $(0.1)$ also had to be estimated by optimization for this well. The fluid entry in this well was reported to occur at the contact between the gabbro and underlying Triassic metasediments. From isotherms in site cross-sections made available by Alta Rock, a temperature near $170^{\circ} \mathrm{C}$ prevails at the contact between both lithologies in this well, which would support the GeoT results. However, classical geothermometers yield temperatures that are lower by up to $\sim 50^{\circ} \mathrm{C}$. The $\mathrm{Al}$ and $\mathrm{Mg}$ concentrations estimated by optimization are similar to results for well 45-14 (Table 2). 
Appendix E: DE-FOA-0000522

Table 1. Chemical composition of selected representative thermal waters from Dixie Valley (Goff et al.,2002).

\begin{tabular}{|c|c|c|c|c|c|c|c|c|c|c|c|c|c|c|c|}
\hline & Samples & $\begin{array}{c}\mathrm{T} \\
\left({ }^{\circ} \mathrm{C}\right)\end{array}$ & sf & $\mathrm{pH}$ & $\mathrm{SiO}_{2}$ & $\mathrm{Na}$ & $\mathrm{K}$ & $\mathrm{Ca}$ & $\mathrm{Mg}$ & $\mathrm{Al}(\mathrm{t})$ & $\mathrm{Al}(\mathrm{d})$ & $\mathrm{Fe}$ & $\mathrm{Cl}$ & $\mathrm{SO}_{4}$ & $\mathrm{HCO}_{3}$ \\
\hline \multirow{17}{*}{$\frac{\infty}{\overline{0}}$} & $73-7$ & $\sim 165$ & 0.16 & 9.0 & 580 & 508 & 74 & 9.0 & 0.02 & 1.04 & 0.06 & 0.04 & 594 & 207 & 161 \\
\hline & $76-7$ & 163 & 0.18 & 9.1 & 599 & 474 & 70 & 8.5 & 0.03 & 1.12 & 0.05 & $<0.01$ & 524 & 201 & 173 \\
\hline & $74-7$ & n.m. & 0.16 & 9.1 & 586 & 500 & 72 & 9.2 & $<0.01$ & 1.13 & 0.08 & 0.01 & 584 & 204 & 183 \\
\hline & $82 \mathrm{~A}-7$ & n.m. & 0.16 & 9.1 & 556 & 495 & 73 & 10 & $<0.01$ & 1.02 & 0.04 & 0.02 & 575 & 212 & 164 \\
\hline & $63-7$ & n.m. & 0.15 & 9.0 & 516 & 510 & 77 & 8.7 & $<0.01$ & 1.03 & 0.02 & $<0.01$ & 560 & 214 & 153 \\
\hline & $73 \mathrm{~B}-7$ & 174 & 0.15 & 9.0 & 511 & 500 & 74 & 8.4 & $<0.01$ & 0.97 & 0.04 & $<0.01$ & 561 & 216 & 153 \\
\hline & $27-33$ & $\sim 165$ & 0.16 & 8.8 & 627 & 423 & 67 & 7.7 & $<0.01$ & 1.44 & 0.04 & $<0.01$ & 443 & 183 & 188 \\
\hline & $37-33$ & n.m. & 0.16 & 9.2 & 621 & 431 & 69 & 7.2 & 0.02 & 0.99 & 0.02 & 0.02 & 475 & 191 & 172 \\
\hline & 28-33 & n.m. & 0.16 & 9.4 & 531 & 412 & 66 & 7.2 & 0.03 & 1.36 & 0.04 & $<0.01$ & 441 & 199 & 178 \\
\hline & 45-33 pre & n.m. & 0.17 & 9.1 & 589 & 370 & 59 & 1.3 & 0.04 & 1.52 & n.a. & n.a. & 320 & 149 & 311 \\
\hline & 73-7 pre & n.m. & 0.20 & 9.0 & 548 & 380 & 59 & 1.2 & $<0.01$ & 0.99 & n.a. & n.a. & 363 & 150 & 291 \\
\hline & 74-7 pre & n.m. & 0.20 & 9.1 & 574 & 413 & 62 & 1.1 & $<0.01$ & 1.10 & n.a. & n.a. & 396 & 159 & 309 \\
\hline & 76-7 pre & n.m. & 0.19 & 9.2 & 563 & 403 & 54 & 1.5 & $<0.01$ & 1.19 & n.a. & n.a. & 402 & 158 & 286 \\
\hline & $32-18$ pre & n.m. & n.m. & 7.6 & 484 & 406 & 43 & 2.1 & $<0.01$ & 0.75 & n.a. & n.a. & 428 & 150 & 223 \\
\hline & $65-18$ pre & n.m. & n.m. & 8.9 & 417 & 440 & 41 & 1.2 & $<0.01$ & 0.69 & n.a. & n.a. & 404 & 162 & 334 \\
\hline & $45-14$ & 125 & n.m. & 7.0 & 285 & 432 & 41 & 23 & 0.04 & 0.23 & n.a. & 0.07 & 481 & 195 & 101 \\
\hline & $62-21$ & 76 & n.m. & 6.9 & 172 & 513 & 17 & 6.1 & 0.41 & 0.07 & 0.09 & 0.24 & 80 & 219 & 836 \\
\hline
\end{tabular}

$\mathrm{Al}(\mathrm{t})$ is total $0.45 \mu \mathrm{m}$ filtered $\mathrm{Al}$ concentration; $\mathrm{Al}(\mathrm{d})$ is dissolved $0.2 \mu \mathrm{m}$ filtered $\mathrm{Al}$ concentration. All concentrations in $\mathrm{mg} / \mathrm{l}$ except for $\mathrm{Mg}$ in $\mu \mathrm{g} / \mathrm{l}$. 
Table 2. Results of solute geothermometry using classical geothermometers, optimized multicomponent geothermometry with GeoT, and values of parameters estimated by numerical optimization. The classical geothermometers are applied to the reconstructed deep fluids using GeoT. $n$ is the number of waters processed simultaneously, as shown.

\begin{tabular}{|c|c|c|c|c|c|c|c|c|c|c|c|c|c|c|}
\hline & $\#$ & $\mathrm{n}$ & Samples & $\mathrm{T}_{\text {quartz* }}$ & $\mathrm{T}_{\mathrm{Na}-\mathrm{K}}$ & $\mathrm{T}_{\mathrm{Na}-\mathrm{K}-\mathrm{Ca}}$ & $\mathrm{T}_{\mathrm{K}-\mathrm{Mg}}$ & $\mathrm{T}_{\text {geoT }}$ & $\mathrm{T}_{\text {stder }}$ & \multirow{22}{*}{ 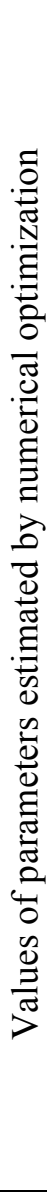 } & $\mathrm{Al}$ & $\mathrm{Mg}$ & cfact & sf \\
\hline \multirow{21}{*}{$\frac{n}{\overline{0}}$} & 1 & 6 & $73-7$ & 255 & 252 & 232 & 241 & 252 & 5.7 & & 0.42 & 0.58 & 0.85 & 1 \\
\hline & & & $76-7$ & 255 & 252 & 231 & 230 & 252 & 5.7 & & 0.56 & 0.49 & 0.80 & I \\
\hline & & & $74-7$ & 256 & 251 & 230 & / & 252 & 5.7 & & 0.42 & 0.49 & 0.85 & I \\
\hline & & & $82 \mathrm{~A}-7$ & 250 & 252 & 231 & / & 252 & 2.1 & & 0.62 & 0.49 & 0.81 & I \\
\hline & & & $63-7$ & 243 & 255 & 235 & / & 248 & 6.5 & & 0.35 & 0.84 & 0.87 & I \\
\hline & & & 73B-7 & 243 & 253 & 233 & I & 244 & 3.3 & & 0.42 & 1.06 & 0.86 & / \\
\hline & \multicolumn{3}{|c|}{ average } & 250 & 253 & 232 & 236 & 250 & 4.8 & & 0.47 & 0.66 & 0.84 & \\
\hline & \multirow[t]{3}{*}{2} & \multirow[t]{3}{*}{3} & $27-33$ & 264 & 260 & 235 & 1 & 248 & 6.5 & & 0.40 & 0.47 & 0.85 & 1 \\
\hline & & & $37-33$ & 263 & 261 & 237 & 237 & 248 & 6.5 & & 0.35 & 0.46 & 0.85 & I \\
\hline & & & 28-33 & 245 & 260 & 235 & 224 & 244 & 3.4 & & 0.44 & 0.51 & 0.85 & 1 \\
\hline & \multicolumn{3}{|c|}{ average } & 257 & 260 & 236 & 231 & 247 & 5 & & 0.39 & 0.48 & 0.85 & \\
\hline & 3 & 1 & 45-33 pre & 255 & 261 & 254 & 212 & 256 & 8.4 & & 0.35 & 0.90 & 1 & 1 \\
\hline & \multirow[t]{4}{*}{4} & \multirow[t]{3}{*}{3} & 73-7 pre & 244 & 258 & 252 & 1 & 248 & 11 & & 0.29 & 0.69 & 1 & 1 \\
\hline & & & 74-7 pre & 249 & 254 & 252 & / & 244 & 13 & & 0.25 & 0.70 & / & I \\
\hline & & & 76-7 pre & 248 & 244 & 241 & 1 & 248 & 12 & & 0.34 & 0.49 & 1 & 1 \\
\hline & & average & & 247 & 252 & 248 & & 247 & 12 & & 0.29 & 0.62 & & \\
\hline & \multirow[t]{3}{*}{5} & \multirow[t]{2}{*}{2} & $32-18$ pre & 235 & 223 & 224 & 1 & 248 & 7.66 & & 0.32 & 0.94 & 1 & 0.18 \\
\hline & & & $65-18$ pre & 224 & 210 & 221 & I & 244 & 3.27 & & 0.52 & 0.42 & 1 & 0.16 \\
\hline & & average & & 229 & 217 & 223 & & 246 & 5.5 & & 0.42 & 0.68 & & 0.17 \\
\hline & 6 & 1 & $45-14$ & 200 & 213 & 194 & 198 & 224 & 2.0 & & 0.43 & 6.21 & 1 & 0.08 \\
\hline & 7 & 1 & $62-21$ & 164 & 138 & 153 & 124 & 176 & 3.3 & & 0.19 & 7.90 & 1 & 0.1 \\
\hline
\end{tabular}

Quartz, Na-K equations are respectively from Fournier and Potter (1982; conductive cooling formula) and from Fournier (1979); Na-K-Ca from Fournier and Truesdell (1973) and K-Mg from Giggenbach (1988). The Al concentration is in $\mathrm{mg} / \mathrm{l}$, and the $\mathrm{Mg}$ concentration in $\mu \mathrm{g} / \mathrm{l}$. Temperature is in degrees Celsius. sf: steam fraction; $\mathrm{n}$ : numbers of samples processed simultaneously in the optimization. *: quartz geothermometer was calculated taking into account the measured or optimized steam fractions. When $\mathrm{Mg}$ concentrations are below limit detection, the K$\mathrm{Mg}$ geothermometer is not calculated. 